$9-1-2004$

\title{
Emerging Strains in GCC Labor Markets
}

Ugo Fasano

International Monetary Fund

Rishi Goyal

International Monetary Fund

Follow this and additional works at: https://ecommons.luc.edu/meea

Part of the Economics Commons

\section{Recommended Citation}

Fasano, Ugo and Goyal, Rishi, "Emerging Strains in GCC Labor Markets". Topics in Middle Eastern and North African Economies, electronic journal, 6, Middle East Economic Association and Loyola University Chicago, 2004, http://www.luc.edu/orgs/meea/

This Article is brought to you for free and open access by the Journals and Magazines at Loyola eCommons. It has been accepted for inclusion in Topics in Middle Eastern and North African Economies by an authorized administrator of Loyola eCommons. For more information, please contact ecommons@luc.edu. 


\title{
Emerging Strains in GCC Labor Markets
}

\author{
Ugo Fasano and Rishi Goyal* \\ Email: ufasano@imf.org; rgoyal@,imf.org \\ International Monetary Fund
}

JEL Classification Codes: J30, J60

Keywords: GCC countries, labor market policies, matching function framework

This Working Paper should not be reported as representing the views of the IMF. The views expressed in this Working Paper are those of the author(s) and do not necessarily represent those of the IMF or IMF policy. Working Papers describe research in progress by the author(s) and are published to elicit comments and to further debate. Authorized for distribution by Saade Chami.

\begin{abstract}
Unemployment pressures among nationals are emerging in the Cooperation Council for the Arab States of the Gulf (GCC) [1]. At a time when a rapidly growing number of young nationals are entering the labor force and governments are no longer able to act as employers of first and last resort, the non-oil sector continues to rely on expatriate labor to meet its labor requirements in most GCC countries. In this environment, policymakers face the related challenges of addressing unemployment pressures, while striking a balance between maintaining a liberal foreign labor policy and a reasonable level of competitiveness of the non-oil sector. Using a matching function framework, this paper examines labor market policies that are likely to expand the ability to hire nationals in the non-oil sector. It finds that an effective labor strategy should focus on strengthening investment in human capital, adopting institutional reforms, and promoting a vibrant non-oil economy.
\end{abstract}

\section{INTRODUCTION}

Labor markets in the member countries of the Cooperation Council for the Arab States of the Gulf (GCC) are getting tighter, and unemployment pressures are emerging among young nationals. High growth in the national or local population during the past decades, together with the rising participation of women in the labor force, is translating into a rapidly growing supply of nationals seeking employment. Indeed, the local labor force has been growing at an average annual rate of 4-5 percent over the past decade, and is likely to continue to grow at this pace over the medium term since more than one-third of the local population is below the age of 15 years [2].

Unemployment pressures among nationals have been restrained until recently because most GCC governments have been acting as employers of first and last resort. As a result, 
nationals currently constitute most of the workforce in the public sector. This strategy, however, has practically reached its limits because the wage bill has become too large to keep rising at a time of pressing needs in order to satisfy the demand for government services of a young population (Figure 1). The wage bill now represents more than 10 percent of GDP in most countries. Thus, the responsibility for job creation in the period ahead is likely to rest with the private non-oil sector. This will not be an easy task. During the past three decades, a liberal foreign labor policy has allowed the private non-oil sector to rely mainly on relatively less expensive, better-trained, and more flexible foreign workers to support its development. The result is segmented labor markets as well as a low elasticity of substitution between national and foreign workers.

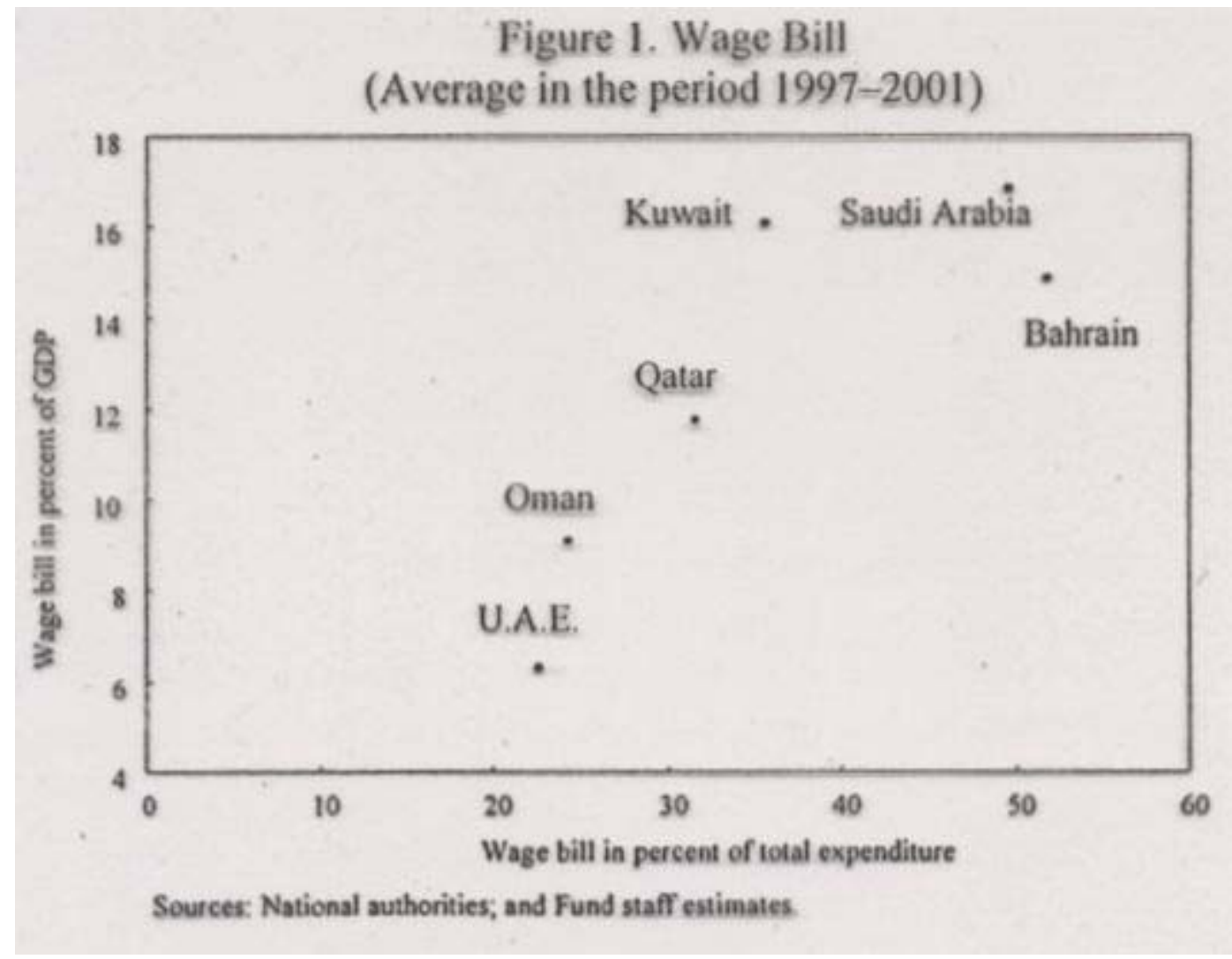

Against this background, policymakers in the GCC countries need to cast the right balance between dealing with the pressures of a rapidly rising local labor force and maintaining a flexible policy toward the hiring of expatriate workers. Otherwise, unemployment among GCC nationals could rise or the competitiveness of the non-oil economy could be compromised. The extent of the problem varies across these countries. Bahrain, Oman, and Saudi Arabia face a more pressing challenge than the other countries, given their relatively large national workforce. Policies are currently geared toward encouraging the replacement of foreign workers with local workers through a combination of mandatory and market-based mechanisms, and promotion of non-oil economic growth.

This paper examines policies to address these labor market challenges facing GCC countries. To this end, a matching function framework is used that, to our knowledge, has not been 
applied before to GCC countries. The next section reviews the main characteristics of the labor market in GCC countries, putting together data from various sources. The third section analyzes labor market dynamics and emerging strains, and the fourth section presents current policy responses and strategies. The fifth section develops an analytical framework to assess current as well as new policies, while the concluding section summarizes the policy lessons.

\section{THE LABOR MARKET IN GCC COUNTRIES}

\section{A. Demographic Profile}

The population of the GCC countries is relatively small. The total population, including expatriates, was estimated at almost 32 million in 2000. Saudi Arabia has the largest population, 22 million, while Bahrain and Qatar have the lowest (Table 1). The expatriate population is about one-fourth of the total in Saudi Arabia, but accounts for more than 70 percent of the total in the smaller countries.

High fertility rates over the past decades have translated into high population growth. Although these rates have declined from 6.4 births per woman in 1980 to the current rate of 3.5 births per woman, they remain high by international standards, particularly in Oman and Saudi Arabia where they are significantly above the regional average. As a result, the GCC population continues to grow at over 3 percent a year [3]. Moreover, a large proportion of the population is aged 0 to 14 years, with the average population age ranging between 26 and 30 years. The dependency ratio (the number of dependents per worker) has also remained high, reaching, for instance, 96 percent in Saudi Arabia in 2000 compared to 72 percent in other Arab countries.

Table 1. Selected Economic Indicators, 2002

\begin{tabular}{rcccccc}
\hline & $\begin{array}{c}\text { Nominal GDP } \\
\text { (In millions of } \\
\text { U.S. dollars) }\end{array}$ & $\begin{array}{c}\text { Nominal GDP } \\
\text { Per Capita (In } \\
\text { U.S. dollars) 1/ }\end{array}$ & $\begin{array}{c}\text { Population } \\
\text { (In millions) 1/ }\end{array}$ & $\begin{array}{c}\text { Overall Fiscal } \\
\text { Balance (In } \\
\text { percent of } \\
\text { GDP) 2/ }\end{array}$ & $\begin{array}{c}\text { Total Govt. } \\
\text { Gross Debt (In } \\
\text { in percent of } \\
\text { GDP) }\end{array}$ & $\begin{array}{c}\text { Proven Oil } \\
\text { Reserves (In } \\
\text { years) 3/ }\end{array}$ \\
\hline Bahrain & 8,506 & 11,619 & 0.7 & 0.8 & 30.3 & 15 \\
Kuwait & 33,215 & 15,098 & 2.2 & 20.6 & 32.9 & 134 \\
Oman & 20,761 & 7,752 & 2.7 & 8.9 & 17 & 16 \\
Qatar & 17,321 & 28,362 & 0.6 & 8.3 & 53.4 & 15 \\
Saudia Arabia & 188,960 & 8,567 & 22.1 & -6 & 97.1 & 85 \\
U.A.E. & 71,187 & 19,613 & 3.6 & -9.3 & 4.5 & 124 \\
GCC & 339,950 & $12,0264 /$ & 31.9 & $2.24 /$ & $66.74 /$ & $844 /$ \\
\hline
\end{tabular}

Sources: National authorities; IMF staff estimates

1/ Including expatriates.

2/ Includes investment income of government foreign assets.

3 / Based on current production.

4/ Weighted average. 


\section{B. An Overview of GCC Labor Markets}

A distinguishing characteristic of labor markets in GCC countries is the large share of expatriate workers in the labor force. The number of foreign workers in these countries increased fivefold from 1.1 million in 1970 to 5.2 million in 2000 [4]. A decade later, the United Nations estimates that the expatriate workforce will have risen to about 5.5 million, of which 3.7 million will reside in Saudi Arabia. Expatriate workers currently account for between 50 percent of employed workers in Saudi Arabia and 90 percent in the U.A.E. An initial inflow of foreign workers took place in the 1970s and early 1980s. The oil price booms at that time resulted in a sharp increase in the demand for labor to build up the GCC countries' physical and social infrastructure. To satisfy this demand, and in light of the relatively small size of local populations, the GCC countries adopted an open door policy to foreign labor.

This policy has been maintained through today in all GCC countries - albeit with some added restrictions over the years - to support the development of non-oil activities [5]. In addition, shortage in skilled national labor has led to continued reliance on foreign labor, while contributing to keeping labor costs down. Access to a highly elastic supply of expatriate workers at internationally competitive wages and flexible contracts has also contributed to avoiding a sharp deterioration in competitiveness of the non-oil sector, usually observed in oil (or other natural resource) rich economies [6]. This access has also been important to increase the resilience of the GCC economies to terms of trade shocks in the context of de facto fixed exchange rate regimes.

Foreign workers are subject to a relatively flexible labor framework. They are hired on limited-duration work assignments based on a sponsorship system. This system facilitates their hiring and dismissal process by the company that brings them into the country on a work contract. Expatriates are attracted to work in the GCC area because their expected earnings is higher than in their home countries - most of them currently come from India and other Asian countries, such as Indonesia and the Philippines [7]. They also benefit from subsidized government services, such as energy, education, and health (although they pay higher rates than nationals), and lack of income and consumption taxes, enhancing their savings opportunities. In fact, in the second half of the 1990s, foreign workers have transferred abroad, on average, between 6 and 11 percent of GDP a year, or between $\$ 2,500-\$ 4,500$ per head (Figure 2). 


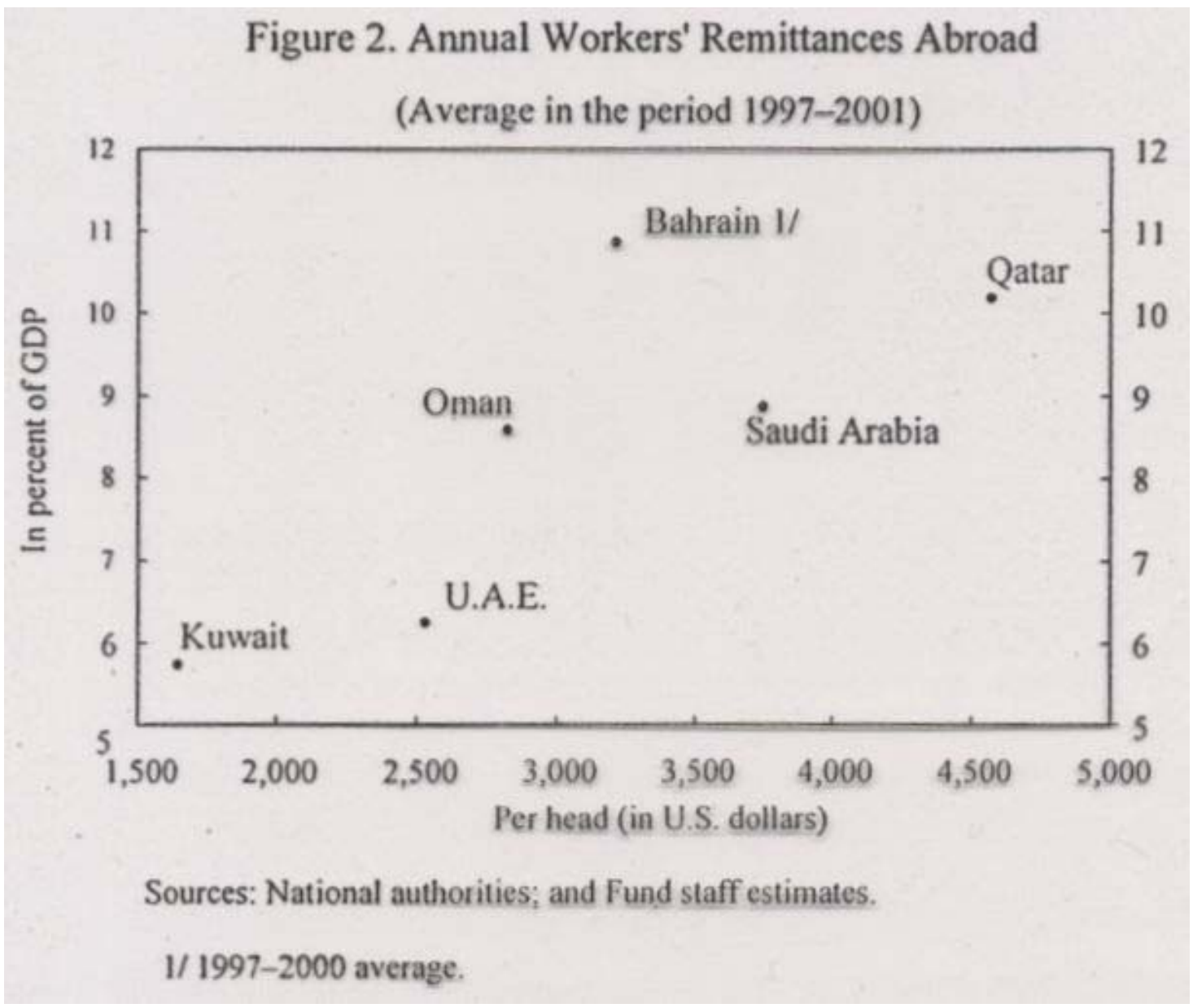

The continued large expatriate presence in GCC countries is also reflected in a segmentation of the labor market in terms of wages, skills, and sectors of employment for national and non-nationals. Underlying this segmentation has been the (implicit) guarantee of employment in the government sector extended to nationals, who prefer to work in this sector because of relatively high wages, job security, social allowances, and generous retirement benefits [8]. Moreover, promotion in the government sector is mainly based on seniority rather than performance, while relatively shorter working hours than in the private sector (and restrictions on foreign investment) have allowed civil servants to run other incomeaugmenting endeavors on the side. All these elements have resulted over time in a large gap between the private and public sector wage and benefit structures, leading to high reservation wages [9]. Consequently, in most GCC countries, except Bahrain and Saudi Arabia, more than 60 percent of the national labor force is employed in the public sector, which has also absorbed most of the national women entering the labor market over the past decade (Figure 3).

In contrast, expatriates work mostly for the non-oil private sector and account, on average, for more than 85 percent of total employed workers in that sector. Private employers prefer to hire non-national workers because their cost is relatively lower-though the difference in cost vis-à-vis national workers is likely to narrow the higher the skill level. Expatriate workers are also relatively better trained and have in practice a more flexible contract 
arrangement that facilitates hiring and firing. In addition, their wages are more flexible. For instance, in the U.A.E., average nominal wages in local currency in the private sector declined by almost 8 percent from 1997-2001, particularly in trade activities. This decline probably reflected weak international labor markets following the Asian financial crisis of 1998 as well as the strengthening of the U.A.E. dirham vis-à-vis currencies in Asia. In contrast, government services' wages increased by 11 percent over the same period, in line with domestic inflation. Moreover, private employers are generally reluctant to train national workers, who may, at any time, leave the company that has incurred their training cost.

Another aspect of the segmentation is a mismatch in skills supplied by national workers and those demanded by the private sector. Although education is free for nationals at all levels, the courses offered often do not reflect the requirements of the market. Nationals take advantage of this free education with the expectation of guaranteed public employment at any level of education and profession. In Qatar, for instance, half of the national workforce in the government sector only held a secondary or lower level of education in 1997-the last year of available information. Indeed, the majority of university graduates in GCC countries pursued studies related to social or religious studies rather than technical fields and business administration, where private sector requirements are the greatest. According to the Arab Human Development Report (2002), 38 percent of graduates from universities in the GCC countries completed studies related to social or Islamic studies, 34 percent in education, but only 11 percent in business administration, and 18 percent in technical fields. In addition, enrollment at the tertiary (or university) level of education, although it has risen over time, has remained low, ranging between 8 percent in Oman and 26 percent in Bahrain and Qatar. Enrollment at the secondary level of education has also been surprisingly low - in most GCC countries remaining below 70 percent, except in Bahrain, where it reached 94 percent in 1998.

Another characteristic of labor markets in GCC countries is the limitations to labor mobility. With nationals confined in the public sector in most GCC countries, expatriates' inter-job mobility is restrained primarily by the sponsorship system. At the regional level, mobility is also limited, even though since the mid-1980s, all GCC citizens have equal rights and free mobility to work across GCC countries. This reflects in part the loss in social benefits, such as land grants and housing loans that a national worker forgoes by not residing in his/her own country. 
Figure 3. Labor Market Segmentation, 2001
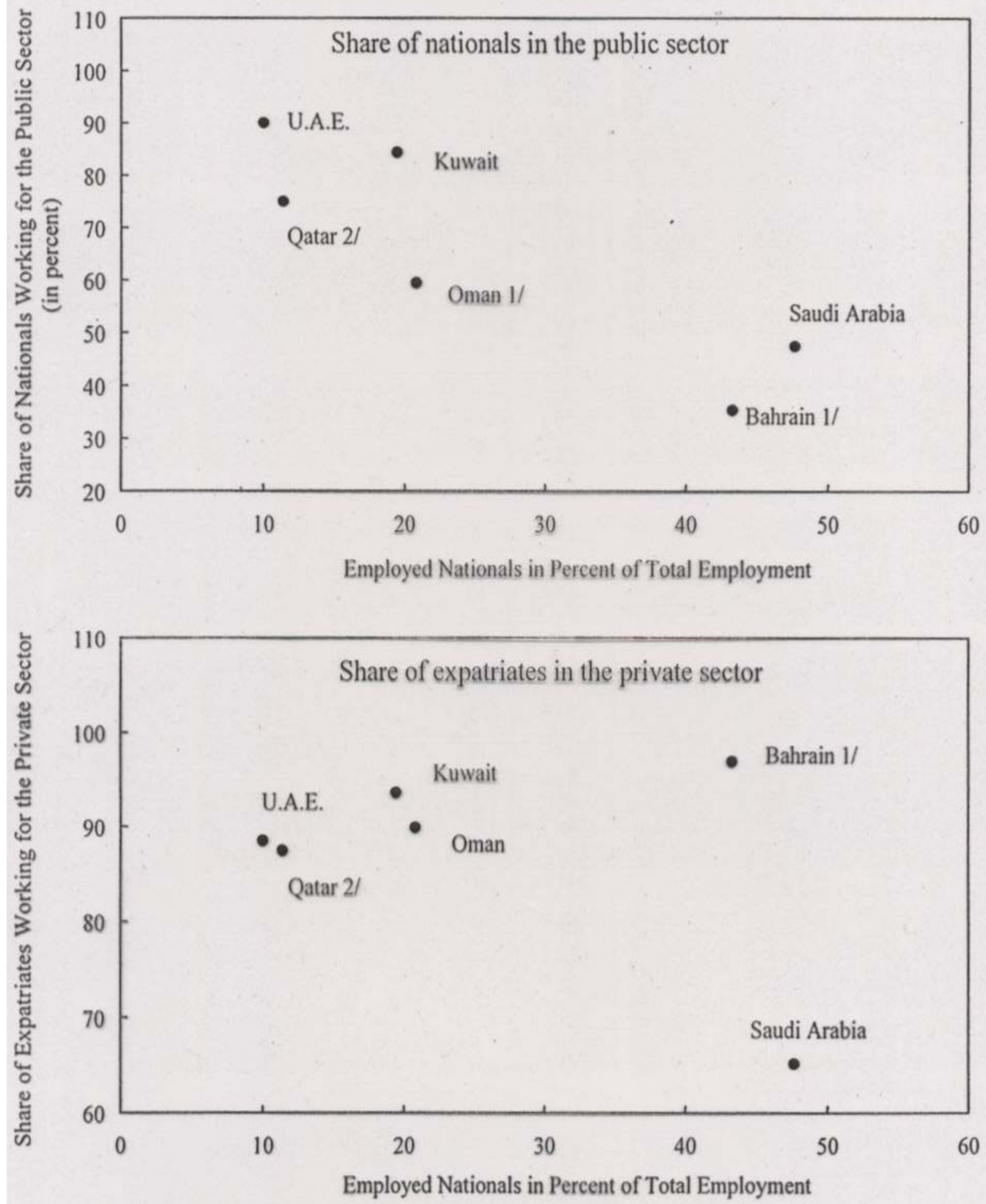

Sources: National Authorities; and Fund staff estimates.

1/ Data for 2000.

2/ Government and mixed sectors only, 1998. 


\section{EMPLOYMENT DYNAMICS: EMERGING STRAINS}

GCC countries have shown some dynamism in employment creation during the 1996-2000 period. The U.A.E. economy has been the most dynamic, creating, on average, more than 100,000 jobs a year in that period while the Saudi economy, which is almost four times larger than the U.A.E. economy, created 130,000 jobs (Figure 4). The Kuwaiti and Omani economies created about the same number of jobs for their nationals, and the Qatari economy seemed to have created relatively the lowest number of jobs in the GCC area (although information is partial).

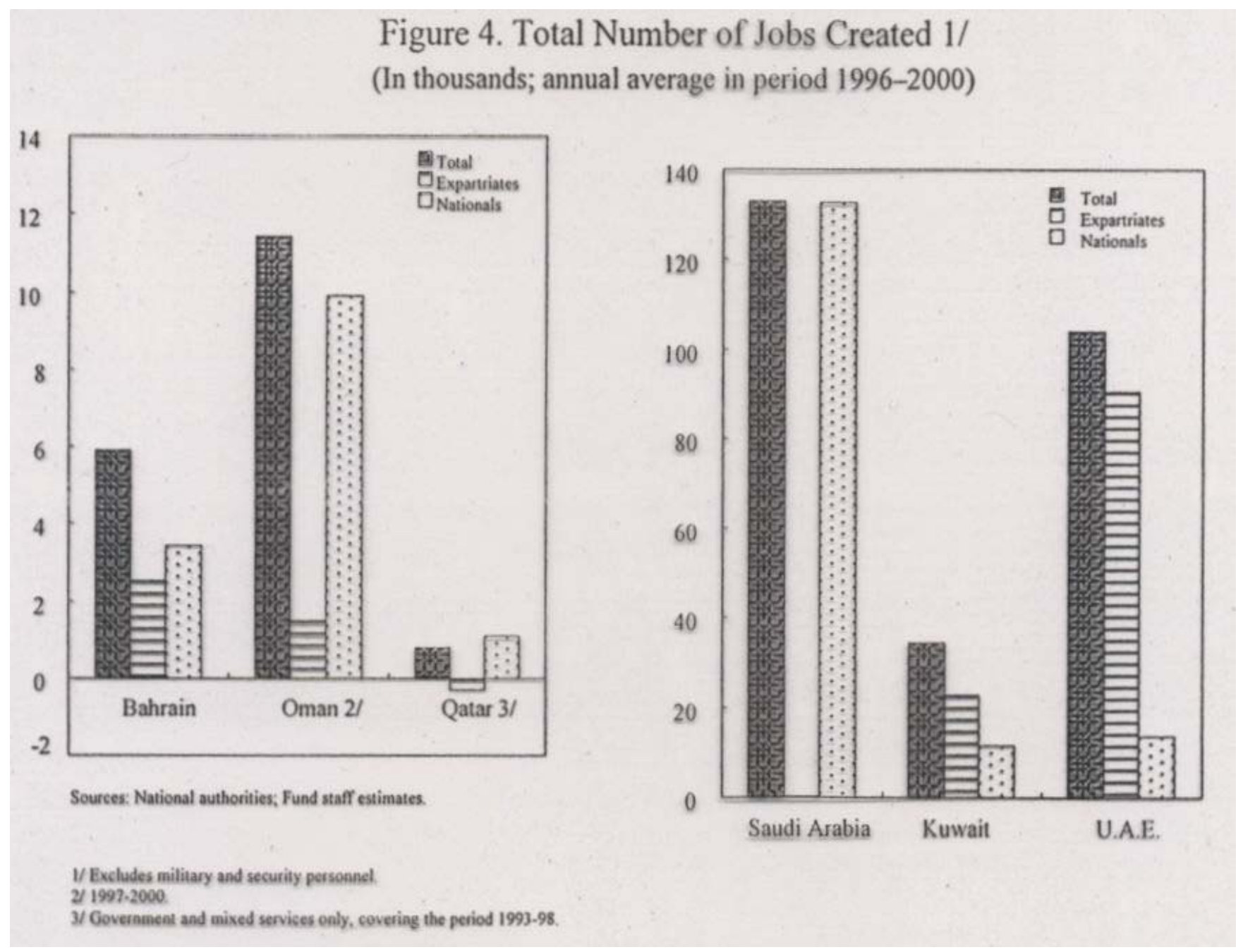

The sources of employment generation and its beneficiaries have also differed across GCC countries. In Bahrain, Oman, and the U.A.E., the majority of the jobs in the past years have 
emanated from the private sector (Figure 5). In contrast, the public sector has continued to account for more than three-quarters of employment growth in Kuwait and about half in Saudi Arabia. In line with policies in place to encourage the hiring of national workers, these workers were the main beneficiaries of job creation in Bahrain, Oman, and Saudi Arabia (Figure 6). In Kuwait and the U.A.E., in contrast, non-nationals reaped a large part of the new jobs, probably reflecting their still low levels of unemployment among nationals. In Qatar, reform in government ministries and the power sector resulted in a large number of non-nationals losing their jobs. Despite this job creation, unemployment pressures seem to have increased in the GCC area, affecting in particular first-time job seekers with a primary or secondary education.

\section{Figure 5. Contribution of the Public and Private Sectors to Employment Growth 1/} (In percent; average in the period 1996-2000)

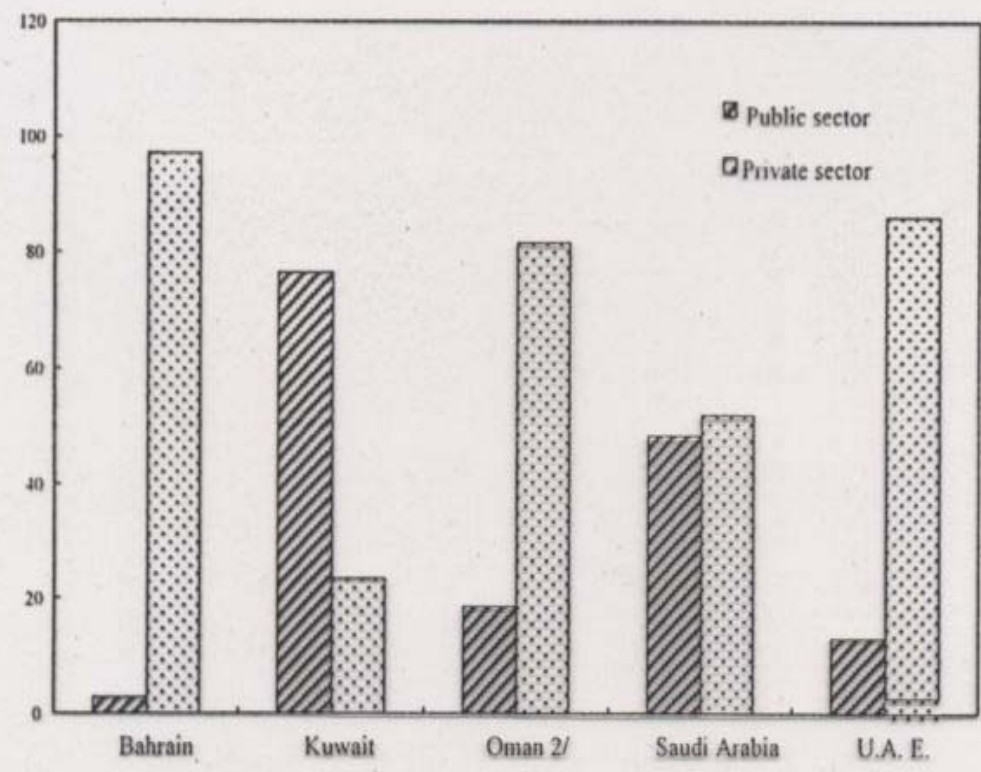


Sources: National authorities and Fund staff estimates

1/ No information available on Qatar

2/Government and mixed services only; covering the period 1993-98

Two main reasons could be advanced to explain these emerging strains in the GCC labor markets. First, in some GCC countries, such as Kuwait and Saudi Arabia, growth of the nonoil sector has remained weak relative to the rate of growth of the domestic labor force. Second, most new jobs in the GCC area have been primarily created in the relatively low-skill and low-wage sectors of the private non-oil economy, which continues to have access to a plentiful supply of expatriate workers at internationally competitive salaries. In fact, most of the new job opportunities created during the second half of the 1990s were in trade, manufacturing, and domestic services, which have traditionally not appealed to national workers. Job opportunities in the finance sector, which requires relatively more skilled workers, have been limited, particularly in the U.A.E., where finance has accounted on average for only 1 percent of total jobs created in 1996-2000 (Figure 7).

The employment elasticity (defined as growth in employment in response to non-oil output growth) in GCC countries ranged between 0.5 and above 1, compared with international averages of less than 0.7 (Figure 8). This relatively high elasticity in some GCC countries is consistent with an expansion of employment in the low-skill, low-wage sectors, as mentioned above.

The substitution of non-nationals with nationals has also encountered several obstacles. First, with most new job opportunities requiring a relatively low level of education and paying relatively low wages, the private sector has continued to offer these jobs mostly to foreign workers. GCC nationals appear unwilling to accept these positions 
Figure 6. Beneficiaries of Job Creation, 1993-2001 1/

(Change in thousands)
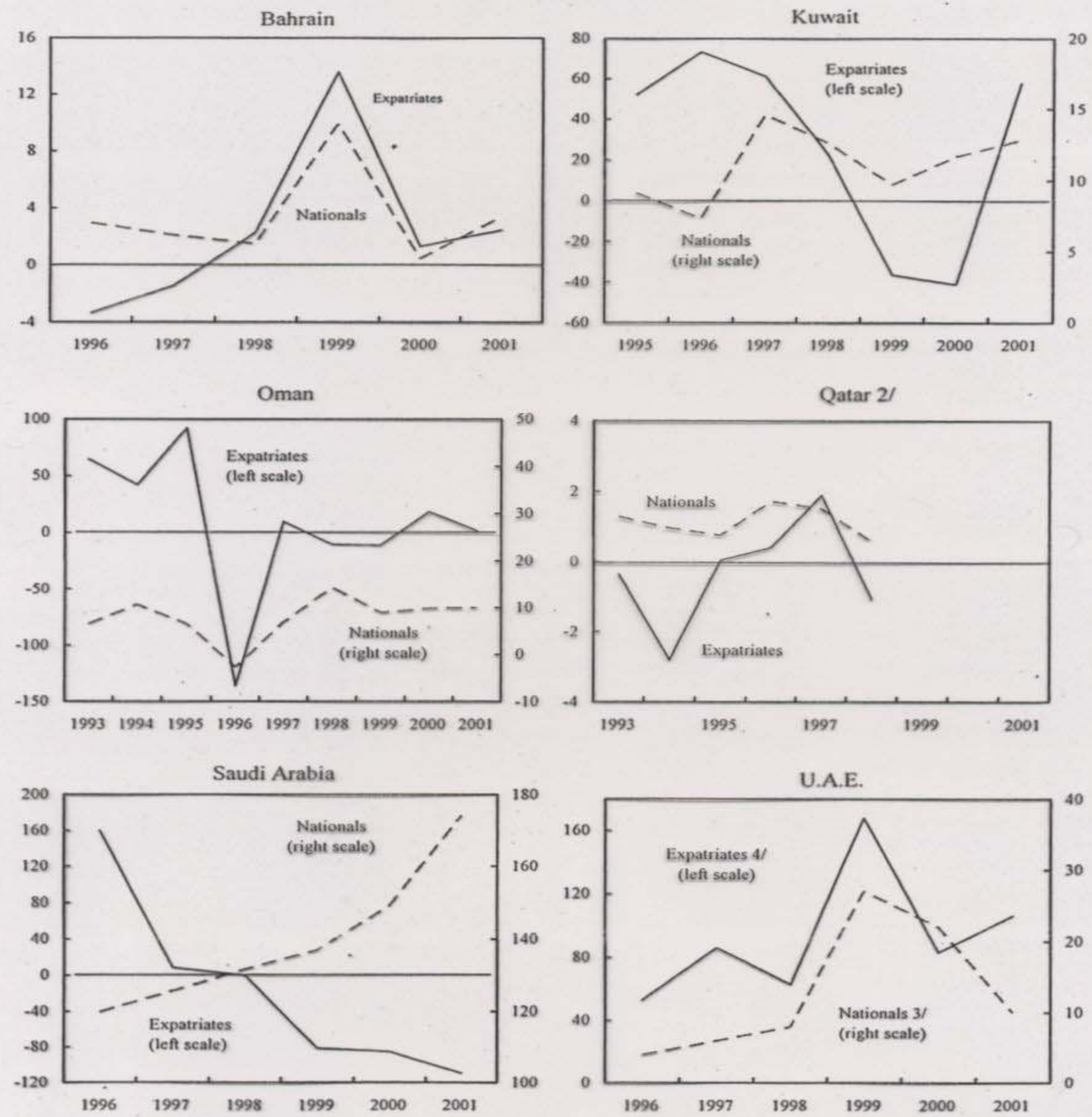

Source: National Authorities.

1/ Excludes defense personnel owing to the lack of information.

2/ Government and mixed sectors only, covering the period 1993-98.

3/ Proxied by change in employment in government services.

4/ Proxied by change in employment in non-government services. 
Figure 7. Job Creation by Main Sub-sectors in the Private Sector

(In percent of total job creation; average in the period 1996-2000)

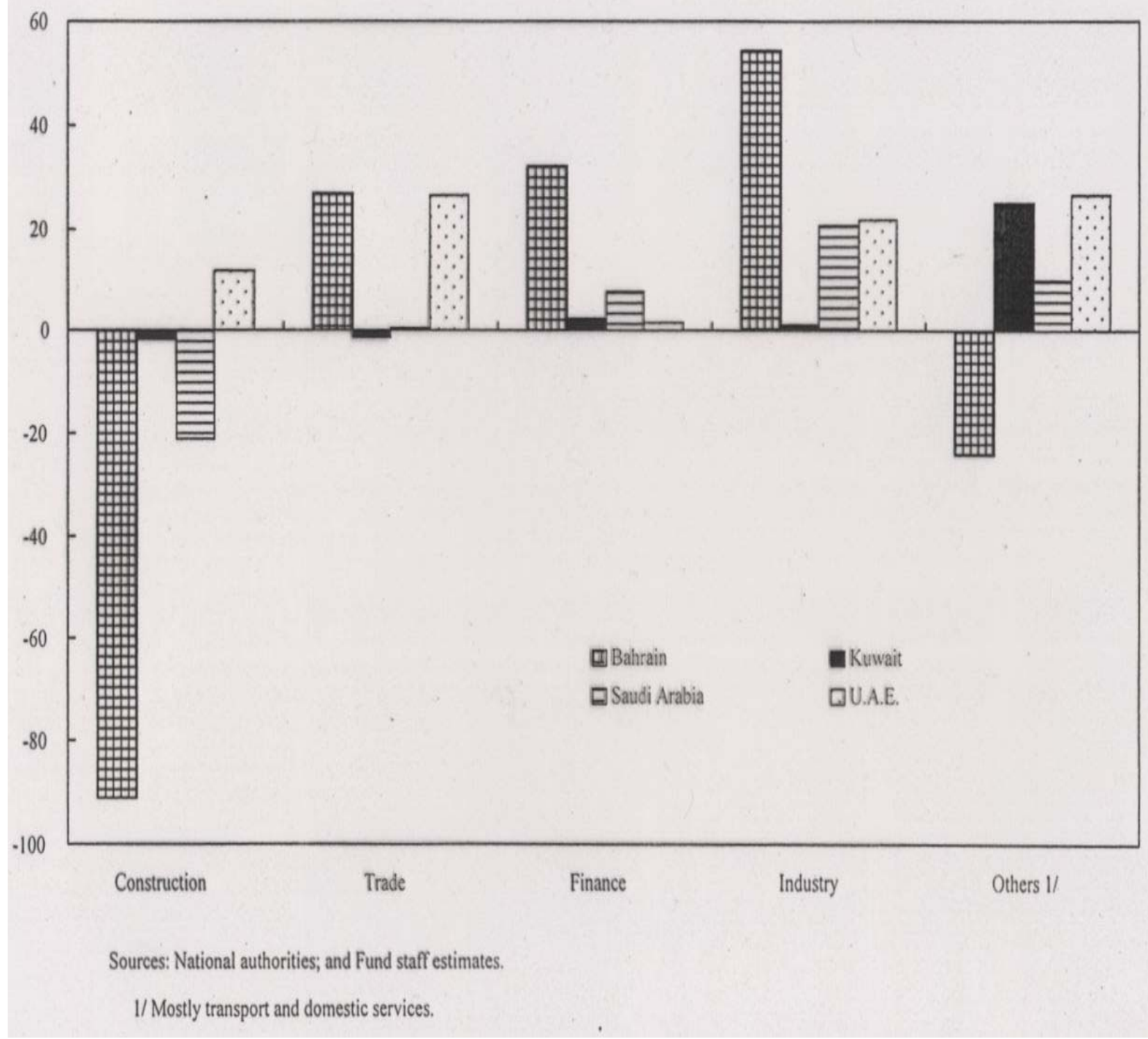




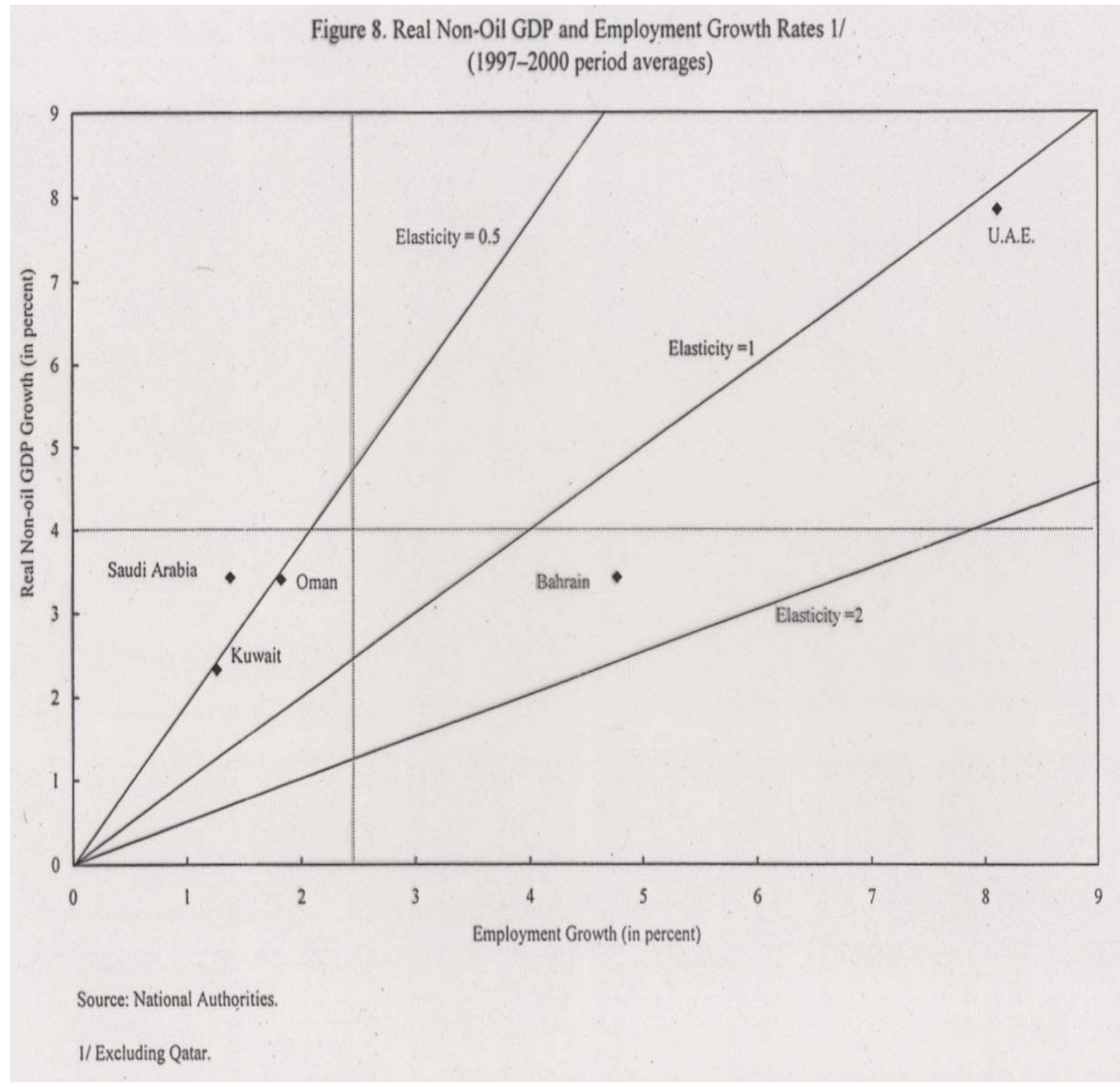

Moreover, the outputs of the education and training systems are insufficiently compatible with labor market requirements, resulting in a skill mismatch. This has hindered the substitution of non-nationals working particularly in skilled positions. Although GCC countries have made important strides in advancing education, the illiteracy rate remains high, and enrollment in secondary and tertiary education remains below enrollment levels prevailing in countries with similar per capita income [10]. For instance, in the private sector (including public enterprises), 43 percent of Qataris had a tertiary level of education compared to 53 percent for expatriates. In the Omani banking sector, the difference was even larger, with one-third of nationals having a tertiary level of education compared to 85 percent of expatriates (Figure 9). 


\section{Figure 9a. Distribution of Workers in the Private Sector by Level of Education, 2000 \\ (In percent)}

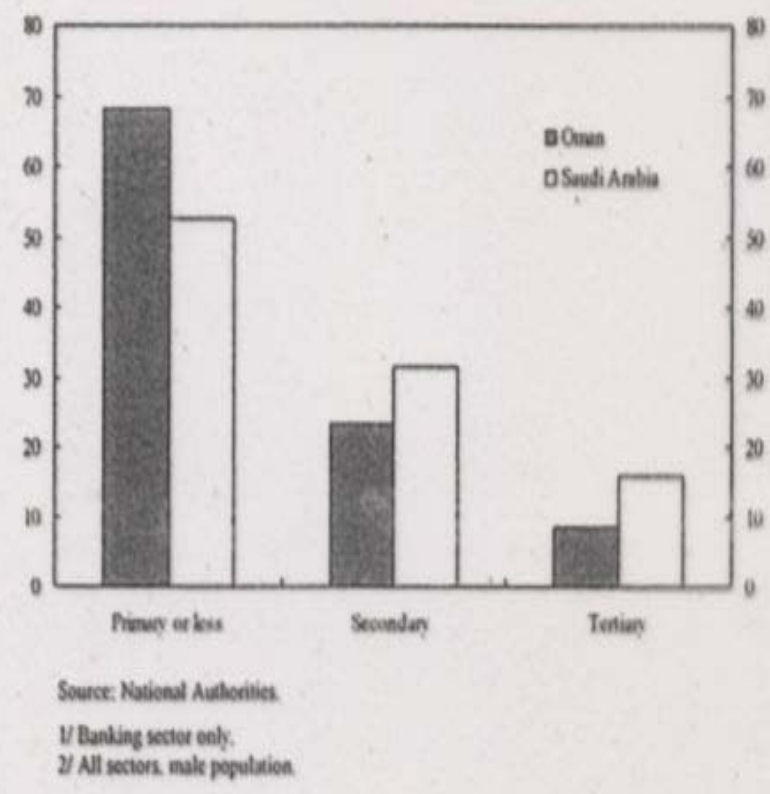

Figure 9b. Level of Education of Nationals

and Expatriates

(In percent)

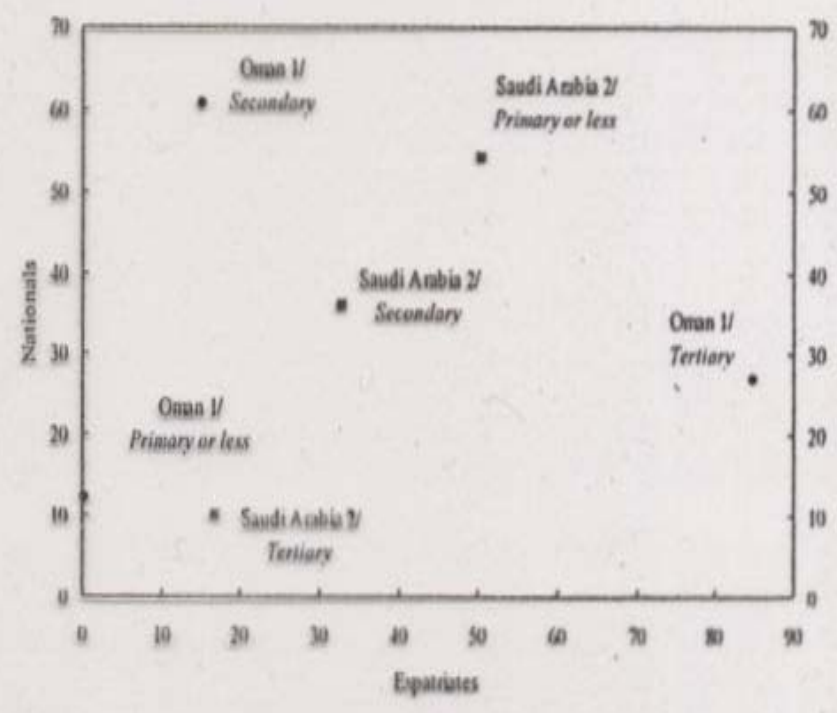

Despite emerging strains in the labor markets, the wage expectations of the national new entrants in the labor force seem to have remained high and rigid. This reflects in part continued expectations by GCC nationals that they will ultimately get a job in the government sector, even though this strategy seems to have reached its limits, becoming an inefficient social safety net [11]. Indeed, as indicated earlier, the size of the wage bill as a share of total expenditures and as a percentage of GDP has risen steadily in most GCC countries during the 1990s. However, information on wages in Saudi Arabia shows that over the 1997-2001 period, average nominal wages for Saudi nationals in all sectors declined by 12 percent (compared to almost a 17 percent fall for non-Saudis). This indicates that nationals may have started to accept lower entry salaries.

\section{Policy Responses And Strategies}

The GCC countries' labor policies have evolved over time to take into account changing labor market conditions. In the 1980s, GCC governments and state-owned enterprises gave priority to nationals in recruitment, resulting in a rapid nationalization of the public sector labor force that helped contain unemployment pressures. By the early 1990s, the share of nationals had already reached more than 80 percent of the civil service and about half in state-owned enterprises in some GCC countries, such as Bahrain (Appendix I).

During the past decade, the focus shifted toward nationalization of the private sector workforce. This shift took place because governments realized that they could not indefinitely take the lead role in employing national workers. In addition, governments have 
started to demand specialized career stream professionals, such as in education and health, because of population dynamics.

To achieve the nationalization of the private sector workforce, a common strategy in GCC countries has been to rely on mandatory measures. These include quantitative targets or quotas on the proportion of nationals employed by private companies in specific professions or sectors (Table 2). Although this strategy has been in place in some GCC countries since the early 1990s, the absorption of national workers by the private sector still remains a challenge. This challenge reflects practical difficulties to enforce the targets for each and every firm, and the private sector's continued unlimited access to expatriate labor at internationally competitive wages [12]. In addition, the GCC authorities have applied quotas in a collaborative rather than in a coercive manner, since forced placement of nationals could result in lower productivity and increased costs to the employer and the economy, hindering long-run growth and ultimately job creation. GCC countries have also relied on administrative measures to increase the relative cost of hiring expatriates, such as regulating the supply of work permits for foreigners. Other measures include adoption of fees or a (training) tax paid by employers to hire foreign workers. Most GCC countries have also provided incentives to private employers to hire nationals by rewarding tenders that meet quota requirements.

More recently, mandatory and administrative measures have become part of a broader effort to simultaneously improve the skills of national workers. In this context, GCC countries have adopted market-based strategies, such as improving training and education in line with private sector requirements. The GCC authorities are intensifying efforts to eliminate the gap between the output of the local educational systems and the requirements of the market and to reduce the rates of repetition and dropouts as well as the average number of years invested for the graduation of students. They have also attempted to equalize the perceived attractiveness of public and private employment by extending retirement benefits and social allowances to all nationals independently of the sector that they work for. Some GCC countries (notably Oman and the U.A.E.) are currently focusing on encouraging self-employment of the national labor force. These efforts have included providing soft loans to young nationals who want to start small businesses, as well as offering training in partnership with established companies to the private sector. 


\section{Table 2. Policy Instruments to Nationalize the Workforce in GCC Countries}

\begin{tabular}{|c|c|c|}
\hline $\begin{array}{l}\text { Create job opportunities for } \\
\text { nationals by moving labor force } \\
\text { closer to market requirements }\end{array}$ & $\begin{array}{c}\text { Encourage the nationalization of the } \\
\text { labor force through market-based } \\
\text { measures }\end{array}$ & $\begin{array}{l}\text { Force the nationalization of the } \\
\text { labor force through } \\
\text { administrative measures }\end{array}$ \\
\hline \begin{tabular}{l}
\multicolumn{1}{c}{ Group 1} \\
Affecting expectations \\
Wage restraint in the public sector \\
Civil service retrenchment \\
Reduction in implicit subsidies \\
Enhance private sector benefits \\
Affecting quality \\
Education reforms \\
Vocational Training \\
Affecting mobility \\
Remove barriers to worker mobility \\
Dismissal legislation for nationals \\
Job search support \\
Information dissemination
\end{tabular} & \begin{tabular}{l}
\multicolumn{1}{c}{ Group 2 } \\
Affeeting price \\
Fees for use of expatriate labor \\
Time specific cash benefits to \\
employ nationals
\end{tabular} & \begin{tabular}{l}
\multicolumn{1}{c}{ Group 3} \\
Affecting quantity \\
$\begin{array}{l}\text { Nationalization of the public-sector } \\
\text { work force }\end{array}$ \\
Quotas on expatriates \\
Quotas on employment of nationals \\
Ban to hire expatriates in certain \\
sectors \\
Tightening of immigration legislation
\end{tabular} \\
\hline Reduce Market Segmentation & & - \\
\hline $\mathrm{C}$ & 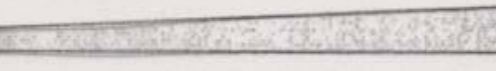 & Short -term Effect \\
\hline + Market -based Strategies & & - \\
\hline$+\quad$ Preserve Private Sector Compe & tiveness & - \\
\hline
\end{tabular}

Source: Megarbane (2001) Table 4.

Given that the extent of the labor market challenge differs across GCC countries, the implementation and emphasis on the policies and strategies mentioned above have also varied from one to another. Qatar, with a relatively small national working age population, has been more lenient in implementing nationalization policies, and is currently relying mainly on improving training and strengthening education to increase the ability to employ nationals in the private sector. The U.A.E. has avoided using quotas, except on the share of nationals employed in the banking sector. This sector demands relatively skilled labor and pays on average the highest wages in the private sector.

Increasing strains in their labor markets have been also reflected in longer search periods after graduation and tightening employment prospects for nationals. The Kuwaiti authorities have recently decided to reinforce mandatory limits or quotas for the employment of 
expatriates in the private sector, even though unemployment is officially estimated at less than 3 percent.

Bahrain, Oman, and Saudi Arabia, in contrast, have more forcefully applied quotas to promote the nationalization of the labor force. This reflects their relatively larger indigenous population and probably relatively higher unemployment rates. In 2001, the Omanization of the labor force reached 81 percent and 91 percent of the hydrocarbon sector and commercial banks, respectively. In other sectors that require less skilled labor, the progress has been modest - reaching, for instance, less than 40 percent of the workforce in the hotel industry.

Limited progress in upgrading the local workforce to meet market requirements and in narrowing the remuneration gap, have continued to hinder the hiring capacity of the local labor force in the private sector. In addition, given that the majority of the expatriates have a low level of education, the nationalization of the labor force through substitution is also limited (to probably less than 30 percent of the expatriate workforce). Robust non-oil economic growth is not expected to be sufficient to create new jobs for nationals in the period ahead. In the case of Saudi Arabia, for instance, the authorities projected in the Seventh Development Plan that the Saudi labor force is likely to rise by 817,000 workers in the period 2000-04. The Saudiization program is expected to provide about 60 percent of new job opportunities, even though private sector real growth is projected to average about 5 percent per year in that period. Most of the new jobs will likely be created in construction, agriculture, trade, and personal services - traditional areas of occupation of expatriate workers. The creation of job opportunities for nationals in the private sector therefore remains a challenge in GCC countries.

\section{A Matching Model of Employment for Nationals}

The policy responses of the GCC authorities may be formally analyzed in a matching model, which is the standard framework for understanding employment dynamics [13]. Such a framework allows for an investigation of the incentives and institutions that may affect the unemployment outcome in the GCC area. In fact, GCC labor market institutions are different from those in Europe and other areas analyzed in the standard literature [14]. Wage bargaining, or the sharing of the firm's surplus, in general, does not apply to the private nonoil sector in the GCC economies. Firms have access to an elastic supply of expatriate workers at internationally competitive wages, and labor unions are absent. As a consequence, workers have negligible bargaining power.

This section presents a slightly modified version of the standard matching model incorporating elements specific to the GCC area [15]. The focus is on the employment of nationals by the private non-oil sector. Therefore, the decisions of nationals in the labor force and of firms are explicitly modeled. The employment decisions of the public sector and the hiring of expatriate workers are not explicitly modeled, but their impact on national employment is captured.

In the model, nationals may either be employed in the private sector or unemployed [16]. Being "unemployed" may be interpreted as being "employed" (or expecting to be employed) in the public sector. If nationals are employed in the private sector, they receive wages, $w$. 
They may also receive benefits from the government while employed in the private sector, $b_{E}$, bringing the total compensation to $w+b_{E}$. Unemployed nationals receive (or expect to receive) benefits, $b_{u}$, which are the public sector wages and benefits. Therefore, $b_{u}$ is the reservation wage below which nationals will not accept private-sector employment. In other words, to even begin the discussion of the ability of the private sector to employ nationals, $w+b_{E}>b_{u}$.

Firms seek to fill jobs. Each filled job or matched position generates output, $y$, for the firm [17]. The firm pays wages, $w$, and earns $y-w$. For the firm to remain competitive, $w$ should be less than or equal to $y$; otherwise, the firm would eventually shut down. If the position is vacant, then the firm searches for an appropriate match. In doing so, it incurs a cost, $c$, which depends on, among other things, the ease with which firms can find substitutes, namely, skilled or semi-skilled expatriate workers, to fill the position. Suppose that, on average, a proportion " $s$ " of existing matches is broken at each point in time; in other words, the separation rate is $s$. When a match is broken, firms pay a separation cost, $c_{s} \geq 0$. For higher values of $c_{s}$, separation is more costly for the firm.

Finally, assume that the process of successfully matching job aspirants with vacancies is described by a matching function, $M=M(U, V)$, where $M$ denotes the number of successful matches, $U$ is the number of unemployed nationals, and $V$ is the number of job vacancies posted by firms. Let $q \equiv M(U, V) / V$ denote the probability of filling a vacancy. Define $\theta \equiv V / U$ as a measure of the tightness of the labor market; as the labor market becomes tighter, $\theta$ increases. If $M(U, V)$ is homogeneous of degree one, then $q$ is a function of $\theta$ : $q(\theta)=M(U, V) / V$. Moreover, the probability of an unemployed national finding a job is $\theta q(\theta)=M(U, V) / U$.

As in the literature, let the matching function be Cobb-Douglas: $M=A U^{\alpha} V^{l-\alpha}$, where $\alpha \in(0,1)$ is the elasticity of matches with respect to unemployment, and $A$ is the efficiency of the matching "technology" or process. Measures that raise $A$ increase the efficiency of the searching and matching process and shorten the time to find a match. Such measures include information dissemination and, more generally, job search support, including internships and the establishment of a national job database.

The unemployment dynamics may now be formally described. In each time period, there is a flow of people into unemployment comprised of new entrants into the labor force (young nationals, including women) and workers whose private-sector jobs are eliminated. At the same time, firms are looking to fill vacancies, and $M$ successful matches are occurring, which constitutes the flow out of unemployment. Therefore, the change in unemployment is given by:

$$
U_{t+1}=U_{t}+\left(N_{t+1}-N_{t}\right)+s\left(N_{t}-U_{t}\right)-\theta_{t} q\left(\theta_{t}\right) U_{t}
$$

where $N_{t}$ is the number of nationals in the work force at time $t$. Dividing by $N_{t}$, substituting for the unemployment rate, $u_{t}=U_{t} / N_{t}$, and re-writing the equation yields:

$$
\left(1+g_{N}\right) u_{t+1}=\left(s+g_{N}\right)+\left[1-s-\theta_{t} q\left(\theta_{t}\right)\right] u_{t},
$$


where $g_{N}$ is the growth rate of the labor force, $\left[s+g_{N}\right]$ is the increase in the unemployment rate owing to the flow into unemployment, and $\theta q(\theta) u$ is the decrease owing to the flow out of unemployment through successful matches.

The above equation can be solved for the steady state unemployment rate, $u^{s s}$. In the steady state, $u$ is constant; $u^{s s}$ is given by:

$$
u^{s s}=\frac{s+g_{N}}{s+g_{N}+\theta^{s s} q\left(\theta^{s s}\right)}
$$

where $\theta^{s}$ is the steady state value for the market tightness indicator, $\theta$. Note that an increase in the labor force growth rate, $g_{N}$, translates into a higher steady-state unemployment rate for a constant level of $\theta q(\theta)$. Thus, the equation captures the dynamics of emerging strains in GCC labor markets owing to demographic pressures.

To complete the characterization of unemployment, a solution for $\theta$ is needed. Consider two scenarios. In the first scenario, wages are given by the internationally competitive wage, $w^{*}$, for skilled and semi-skilled expatriates. Nationals have no bargaining power since firms have access to an elastic supply of expatriate workers at $w^{*}$. In the second scenario, quantitative restrictions on the employment of expatriates give some bargaining power to national workers, which lead to wages being determined within the model.

\section{A. Case 1: No Wage Bargaining}

For the case where private-sector wages are given by $w^{*}$, the steady state unemployment rate, $u^{s s}$, is:

$$
u^{s s}=\frac{1}{1+\left(s+g_{N}\right)^{-1} A^{\frac{1}{\alpha}} c^{1-\frac{1}{\alpha}}\left(y-w^{*}-\beta s c_{s}\right)^{\frac{1}{\alpha}-1}(r+s)^{1-\frac{1}{\alpha}}}
$$

and the comparative statistics are:

$$
\begin{aligned}
& u^{s s}=u\left(y, A, \quad s, \quad c, \quad c_{s}, w^{*}, g_{N}\right) \\
& -\quad+\quad+++
\end{aligned}
$$

The unemployment rate is negatively related to output or productivity, $y$, and matching efficiency, $A$, while it is positively related to the separation rate, $s$, search costs, $c$, separation costs, $c_{s}$, and the international wage rate, $w^{*}$. An increase in $y$, owing to investment in physical and human capital as well as improvements in efficiency (or total factor productivity), leads to greater profits and, hence, increased hiring and a lower unemployment rate. Similarly, improvements in matching efficiency, $A$, such as through increased information dissemination and job support mechanisms, lead to a greater number of matches for a given level of labor market tightness, and hence to a lower unemployment rate.

Measures to reduce the separation rate and search costs would also reduce the unemployment rate. A lower separation rate results in a lower flow into unemployment. Moreover, reduced 
search costs translate into a higher match rate for a given level of resources that a firm puts into searching. Upgrading the skills of the local workforce in line with private sector requirements, through educational reforms and vocational training, would reduce the separation rate and search costs for appropriately trained national employees.

Lower separation costs, including firing costs, make it less costly for a firm to fire national employees as well as hire them. Therefore, labor market reforms that make it easier for firms to separate from national workers while at the same time increasing mobility would lower the unemployment rate among nationals. In addition, measures lowering costs of hiring nationals, including wages, would decrease unemployment. In the model, a drop in the international wage rate, $w^{*}$, increases the profits of the firm for a given revenue level, $y$. Subsidizing the hiring of nationals, through time-specific cash benefits to firms which hire nationals, and rewarding tenders that meet quota requirements would enhance profitability.

Mandatory and administrative measures have an ambiguous effect on unemployment. On one hand, more vacancies would be created with the need to substitute nationals for expatriates [18]. On the other hand, even excluding the impact of these measures on the bargaining power and wages of nationals, such measures could reduce output and productivity, $y$, and hence competitiveness, if nationals have lower human capital than skilled expatriate workers. Improvements in training and education would alleviate the effect on productivity.

In summary, a policy strategy aimed at increasing physical and human capital investment and institutional reform would lower the unemployment rate, $u$. Investment would increase the productivity of the non-oil private sector, $y$. Institutional reforms, such as through labor market reforms, would raise the efficiency of the matching process, $A$, as well as reduce the costs of searching, $c$, and separation, $c_{s}$. In addition, investment in human capital would likely lower the probability of separation, $s$.

\section{B. Case 2: Expatriate Labor Restrictions and Wage Bargaining}

Restrictions on the employment of skilled and semi-skilled expatriates result in an increase in the bargaining power of national workers vis-à-vis firms. As a result, wages are no longer determined by the internationally competitive wage, but will be higher. The steady state unemployment rate for the case of expatriate labor restrictions is obtained by solving the following two equations:

$$
\begin{gathered}
u^{s s}=\frac{1}{1+\left(s+g_{N}\right)^{-1} \theta^{s s} q\left(\theta^{s s}\right)}=\frac{1}{1+\left(s+g_{N}\right)^{-1} A\left(\theta^{s s}\right)^{1-\alpha}} \\
c[1-\beta(1-s)]\left(\theta^{s s}\right)^{\alpha}+c \beta A \phi \theta^{s s}=\beta A(1-\phi)\left(y-\beta s c_{s}+b_{E}-b_{U}\right)
\end{gathered}
$$

Although a single closed-form equation cannot be obtained, the comparative statistics are as follows:

$$
\begin{array}{rlcccccccc}
u^{s s}=u & (y, & A, & s, & c, & c_{s}, & \phi, & b_{E}, & b_{U}, & \left.g_{N}\right) \\
& - & - & + & + & + & + & - & + & +
\end{array}
$$


The difference with the earlier specification is the endogenous determination of wages involving the bargaining power, $\phi$, government benefits to nationals employed in the private sector, $b_{E}$, and government benefits to unemployed nationals, $b_{U}$. The signs of all other variables, the logic, and the policy conclusions remain the same as before.

Greater bargaining power for national workers, reflected in higher values of $\phi$, results in higher wages. Given a level of output or productivity, $y$, higher wages imply lower profitability for firms, which translate into lower probabilities of finding jobs and a higher unemployment rate. Therefore, in addition to potential negative effects on productivity and competitiveness, mandatory and administrative measures could have a deleterious effect on national employment by increasing $\phi$. The stronger the measures, the greater would be the increase in $\phi$ and the more negative would be the effect on employment. Countries that have taken strong measures could see a reversal of employment gains unless other measures, such as improving training and education and enhancing labor market efficiency, are also swiftly implemented.

Reducing the reservation wage of nationals, $b_{U}$, would lower the private-sector wage for nationals and lower the unemployment rate. Moreover, providing greater government benefits to private-sector employed nationals, $b_{E}$, means that workers are willing to accept lower wages from firms, which lowers the cost of hiring nationals. Consequently, the firm's surplus increases and the unemployment rate falls.

\section{Simulations}

There is insufficient data to estimate econometrically the above model for the GCC countries. In fact, there is insufficient data even to calibrate the model and conduct policy experiments. To quantify the impact of the different policy recommendations, we choose a set of baseline parameters that we believe are reasonable. We then use these parameters to calculate elasticities.

For Case 1, we assume the following parameterization, which yields a steady-state unemployment rate of 2.8 percent:

\begin{tabular}{|c|c|c|c|c|c|c|c|c|c|}
\hline Parameter & $s$ & $g_{N}$ & $A$ & $\alpha$ & $c$ & $y$ & $w^{*}$ & $c_{s}$ & $r$ \\
\hline Value & 0.25 & 0.05 & 1 & 0.4 & 0.3 & 1 & 0.5 & 0.3 & 0.05 \\
\hline
\end{tabular}

The elasticity of steady-state unemployment to changes in each of the variables, $y, A, s, c, c_{s}$, and $w^{*}$, may be calculated by changing each of the variables by 10 percent and computing the new steady-state unemployment rate:

\begin{tabular}{|c|c|c|c|}
\hline Variable shocked & $\begin{array}{c}\text { New value of } \\
\text { variable }\end{array}$ & $\begin{array}{c}\text { New steady state } \\
\text { unemployment rate } \\
\text { (In percent) }\end{array}$ & $\begin{array}{c}\text { Elasticity of unemployment with respect } \\
\text { to 10 percent change in variable } \\
\text { (In percent) }\end{array}$ \\
\hline$y$ & 1.1 & 2.1 & -26.4 \\
\hline$A$ & 1.1 & 2.2 & -20.7 \\
\hline$s$ & 0.225 & 2.2 & -21.0 \\
\hline$c$ & 0.27 & 2.4 & -14.3 \\
\hline
\end{tabular}




\begin{tabular}{|c|c|c|c|}
\hline$c_{s}$ & 0.27 & 2.7 & -2.4 \\
\hline$w^{*}$ & 0.45 & 2.4 & -14.9 \\
\hline
\end{tabular}

In other words, a 10 percent increase in $y$ reduces the steady state unemployment rate by 26.4 percent. Similarly, a reduction in the separation rate, $s$, by 10 percent reduces the unemployment rate by 21 percent. Investment in human and physical capital and institutional reforms that enhance productivity in the non-oil sector, $y$, increase matching efficiency, $A$, reduce the separation probability, $s$, and lower search costs, $c$, can be expected to have large effects on the unemployment rate.

Restrictions on the employment of skilled and semi-skilled expatriates that result in an increase in the bargaining power of national workers vis-à-vis firms could increase steady state unemployment significantly. For Case 2, we use the above parameterization, with the following additional assumptions:

\begin{tabular}{|c|c|c|c|}
\hline Parameter & $\phi$ & $b_{E}$ & $b_{U}$ \\
\hline Value & 0.25 & 0.2 & 0.5 \\
\hline
\end{tabular}

These assumptions result in a baseline steady state unemployment rate of 11.3 percent, which is substantially higher than the Case 1 steady state rate of 2.8 percent.

The elasticity of steady-state unemployment is calculated as above:

\begin{tabular}{|c|c|c|c|}
\hline Variable shocked & New value of variable & $\begin{array}{c}\text { New steady state } \\
\text { unemployment rate } \\
\text { (In percent) }\end{array}$ & $\begin{array}{c}\text { Elasticity of unemployment } \\
\text { with respect to 10 percent } \\
\text { change in variable } \\
\text { (In percent) }\end{array}$ \\
\hline$y$ & 1.1 & 10.3 & -9.3 \\
\hline$A$ & 1.1 & 10.2 & -10.0 \\
\hline$s$ & 0.225 & 10.2 & -9.9 \\
\hline$c$ & 0.27 & 10.5 & -6.8 \\
\hline$c_{s}$ & 0.27 & 11.2 & -0.7 \\
\hline$\phi$ & 0.225 & 10.6 & -6.6 \\
\hline$b_{E}$ & 0.22 & 11.1 & -2.1 \\
\hline$b_{U}$ & 0.45 & 10.7 & -5.0 \\
\hline
\end{tabular}

The elasticity of unemployment to changes in each of the variables is lower in Case 2 than in Case 1. That is, the employment response is less when restrictions provide increased bargaining power to nationals. Nevertheless, as mentioned before, measures that raise productivity of the non-oil sector, improve matching efficiency, reduce the separation rate, and lower search costs can have a marked impact on unemployment. Furthermore, less reliance on mandatory measures (and, hence, less bargaining power for national workers) and lower reservation wages reduce the unemployment rate quite significantly. 


\section{Policy Lessons}

To recapitulate, the solution to the emerging labor market strains is closely connected to the development of a vibrant non-oil private sector, investment in human capital, and institutional reform in the labor market. A vibrant non-oil sector is necessary, although not sufficient, to create the needed jobs. Investment in human capital and institutional reform will likely facilitate the process of successfully matching local aspirants with jobs. The specific lessons from the above discussion are as follows:

\section{Employment Costs}

Reducing the relatively high wages in the public sector is likely to lower the reservation wage and increase the willingness of nationals to acquire skills or human capital valuable to private sector employers. Announcing and enforcing strict limits on public sector hiring is likely to further lower the reservation wage by decreasing the likelihood that the public sector will act as the employer of first and last resort for nationals.

Separating wages and social benefits in the public sector, and providing benefits to all working nationals - not just to those employed in the public sector-is likely to reduce the incentive for nationals to seek public sector employment and lower the reservation wage. Furthermore, giving time-specific subsidies for the employment of nationals will likely increase private sector demand for them by reducing their employment costs [19].

Relatively higher firing costs for nationals, including lengthy appeals and investigation of dismissals and direct government intervention, raises their relative cost of employment, thus reducing demand. Therefore, establishing a clear set of rules for the appeal of dismissals, including fines or penalties associated with wrongful dismissals, and a mechanism for the rapid resolution of appeals are likely to lower the relative cost of employing nationals.

\section{Skill Acquisition}

Enhancing the human capital of nationals and the acquisition of skills that are valuable to the private sector is likely to increase demand and employment. To this end, providing education, including vocational training, reforming school curricula, encouraging firms to establish internships, awarding scholarships as well as targeted training vouchers, and fostering self employment will likely build necessary skills and expertise among prospective national workers.

\section{Investment in Capital and Knowledge}

Facilitating the adoption of new technologies and the accumulation of capital is also likely to increase private sector demand and employment by raising the productivity of nationals [20]. Continued outsourcing of government services and extending 100 percent foreign ownership of companies to all non-oil economic activities will likely promote competition and improve resource allocation, leading to higher productivity and investment. 


\section{CONCLUSIONS}

Labor market strains are emerging in GCC countries because of a rapidly growing labor force. Economic diversification efforts under way address this issue by enhancing non-oil growth and in turn job creation. However, these efforts need to be complemented with investment in human capital and adoption of institutional reforms in the labor market to facilitate the substitution of national workers for expatriate workers without hindering employment dynamics and the economy's competitiveness.

An effective employment strategy for nationals in GCC countries would include:

- Increasing the relative attractiveness of working in the private sector by lowering the wage differential between the public and private sectors; making social benefits available to all working nationals; irrespective of sector of employment; and announcing strict limits on public sector employment.

- $\quad$ Reducing disparities in labor mobility by creating a level playing field between hiring or firing national workers vis-à-vis expatriate workers.

- $\quad$ Encouraging skill acquisition among nationals by strengthening educational and vocational training, providing time-specific incentives, such as subsidies to companies for training and scholarships, and promoting self-employment.

- $\quad$ Facilitating improvements in productivity and investment in capital by outsourcing government services, and extending the possibility of majority foreign ownership in the economy.

- $\quad$ Using price- and market-based rather than quantity-based market interventions to encourage the substitution of national workers for expatriate workers and to maintain labor market flexibility, which is key to non-oil growth and competitiveness. The impact of quantity-based market intervention on employment generation for nationals is at best ambiguous.

Future research on this subject could gather more data to calibrate the model presented above and precisely quantify the impact of the different policy recommendations. The model presented above could also be developed further to explicitly include the hiring of expatriate workers and the degree of complementarities or substitutability between the different skill types of expatriate workers and national workers. 


\section{APPENDIX I}

\section{Summary of Current Labor Market Policies in the GCC Countries}

\begin{tabular}{|c|c|c|c|c|c|}
\hline & Bahrain & Kuwait & Oman & Saudi Arabia & U.A.E. \\
\hline $\begin{array}{l}\text { Substitution } \\
\text { policies in the } \\
\text { government } \\
\text { sector }\end{array}$ & $\begin{array}{l}\text { Public sector } \\
\text { gives priority to } \\
\text { nationals. }\end{array}$ & $\begin{array}{l}\text { Public sector gives } \\
\text { priority to nationals. }\end{array}$ & $\begin{array}{l}\text { Public sector gives } \\
\text { priority to nationals. } \\
\text { Government intention is } \\
\text { to increase Omanization } \\
\text { rate in the public sector to } \\
95 \text { percent by } 2020 .\end{array}$ & $\begin{array}{c}\text { Public sector gives } \\
\text { priority to nationals } \\
\text { with an indicative target } \\
\text { of } 85 \text { percent of Saudis. }\end{array}$ & $\begin{array}{c}\text { A } 1992 \\
\text { regulation } \\
\text { requires that } \\
\text { ministries hire } \\
\text { expatriates only } \\
\text { if no national on } \\
\text { the list of job } \\
\text { seekers has the } \\
\text { necessary } \\
\text { qualifications. }\end{array}$ \\
\hline $\begin{array}{c}\text { Quotas on } \\
\text { expatriates }\end{array}$ & $\begin{array}{l}\text { Restriction in the } \\
\text { number of } \\
\text { approved work } \\
\text { visas. }\end{array}$ & $\begin{array}{c}\text { Restriction in the } \\
\text { number of approved } \\
\text { work visas. }\end{array}$ & $\begin{array}{l}\text { Ceilings by region are set } \\
\text { on the annual influx of } \\
\text { expatriates. Labor permits } \\
\text { are issued in priority to } \\
\text { firms that meet their } \\
\text { Omanization target. }\end{array}$ & $\begin{array}{c}\text { Restriction in the } \\
\text { number of approved } \\
\text { work visas. }\end{array}$ & $\begin{array}{l}\text { Restriction in the } \\
\text { number of } \\
\text { approved work } \\
\text { visas. }\end{array}$ \\
\hline $\begin{array}{c}\text { Ban to hire } \\
\text { expatriates in } \\
\text { certain } \\
\text { industries }\end{array}$ & & $\begin{array}{l}\text { Work permit issued } \\
\text { for foreign workers } \\
\text { are confined to } \\
\text { selected activities in } \\
\text { the private sector } \\
\text { (1994 Amendment } \\
107 \text { to Labor Law). }\end{array}$ & $\begin{array}{l}\text { Ban on expatriates } \\
\text { performing jobs that do } \\
\text { not require special } \\
\text { training programs. }\end{array}$ & $\begin{array}{c}\text { Sector specific } \\
\text { restrictions on issuing } \\
\text { work permits for foreign } \\
\text { workers. Issuance and } \\
\text { renewal of work permits } \\
\text { were stopped in many } \\
\text { unskilled professions. } \\
\text { Some job categories, } \\
\text { such as administration, } \\
\text { security, and recently } \\
\text { agricultural products } \\
\text { trading in the municipal } \\
\text { market, are reserved for } \\
\text { nationals. }\end{array}$ & \\
\hline
\end{tabular}




\begin{tabular}{|c|c|c|c|c|c|}
\hline $\begin{array}{l}\text { Fees for use of } \\
\text { expatriate labor }\end{array}$ & $\begin{array}{l}\text { Fee on a visa for } \\
\text { a foreign } \\
\text { worker. } \\
\text { Companies with } \\
\text { more than } 100 \\
\text { workers and do } \\
\text { not provide } \\
\text { internal training } \\
\text { pay a charge for } \\
\text { training to the } \\
\text { ministry of labor } \\
\text { and social affairs } \\
\text { equivalent to } \\
1 \text { percent of total } \\
\text { annual wages of } \\
\text { the local labor } \\
\text { force and } \\
3 \text { percent of } \\
\text { foreign workers' } \\
\text { wages. }\end{array}$ & $\begin{array}{l}\text { Fees for visas, work } \\
\text { permits, and } \\
\text { residence permits } \\
\text { were raised. Flat fee } \\
\text { on hiring domestic } \\
\text { servants. }\end{array}$ & $\begin{array}{l}\text { Since 1994, a fee equal to } \\
7 \text { percent of the worker's } \\
\text { annual salary is imposed } \\
\text { on the use of foreign } \\
\text { labor. Fee revenues are } \\
\text { used as "training } \\
\text { contributions." }\end{array}$ & $\begin{array}{c}\text { Fees for visas, work } \\
\text { permits and residence } \\
\text { permits. }\end{array}$ & $\begin{array}{c}\text { Fees for issuing } \\
\text { a work visa and } \\
\text { for visa renewal. } \\
\text { Annual fee } \\
\text { payable by } \\
\text { expatriate } \\
\text { employers of } \\
\text { household help. }\end{array}$ \\
\hline & Bahrain & Kuwait & Oman & Saudi Arabia & U.A.E. \\
\hline $\begin{array}{c}\text { Cash benefits } \\
\text { and other } \\
\text { incentives to } \\
\text { employ nationals }\end{array}$ & $\begin{array}{l}\text { Payments of up } \\
\text { to BD } 1000 \text { a } \\
\text { year to midsize } \\
\text { private } \\
\text { manufacturing } \\
\text { firms in which } \\
30 \text { percent of the } \\
\text { workforce is } \\
\text { Bahraini. }\end{array}$ & $\begin{array}{c}\text { Government } \\
\text { contracts are only } \\
\text { provided to } \\
\text { domestic firms in } \\
\text { which } 40 \text { percent of } \\
\text { the labor force is } \\
\text { national, earning at } \\
\text { least } 40 \text { percent of } \\
\text { the firm's total wage } \\
\text { bill. }\end{array}$ & $\begin{array}{l}\text { Firms that meet their } \\
\text { Omanization target are } \\
\text { given priority } \\
\text { consideration for } \\
\text { concessionary loans, } \\
\text { exemptions from duties } \\
\text { on machinery and raw } \\
\text { materials, and priority in } \\
\text { the awarding of } \\
\text { government contracts. } \\
\text { Soft finance, tax } \\
\text { exemptions, and business } \\
\text { support services are } \\
\text { offered to nationals who } \\
\text { create their own business. }\end{array}$ & $\begin{array}{l}\text { Firms that do not } \\
\text { comply with the } \\
\text { Saudiization program } \\
\text { could be subject to } \\
\text { refusal of visa requests } \\
\text { or work permit } \\
\text { renewals, and could be } \\
\text { banned from } \\
\text { government contracts } \\
\text { bids, loans, and } \\
\text { subsidies }\end{array}$ & \\
\hline $\begin{array}{c}\text { Education and } \\
\text { training }\end{array}$ & $\begin{array}{l}\text { The Bahraini } \\
\text { Training Center } \\
\text { has been } \\
\text { reformed and } \\
\text { empowered to } \\
\text { expand publicly- } \\
\text { provided } \\
\text { training. }\end{array}$ & $\begin{array}{l}\text { The government has } \\
\text { initiated several } \\
\text { steps in the area of } \\
\text { training to be } \\
\text { financed by a } \\
2.5 \text { percent tax on } \\
\text { companies listed on } \\
\text { the Kuwait Stock } \\
\text { Exchange. }\end{array}$ & $\begin{array}{l}\text { The Vocational Training } \\
\text { System, financed with the } \\
\text { proceeds of the fees on } \\
\text { expatriate labor, ia a } \\
\text { system of privately- } \\
\text { provided training to } \\
\text { nationals who must first } \\
\text { be matched with } \\
\text { employers that commit to } \\
\text { hiring them after the } \\
\text { completion of the } \\
\text { training. }\end{array}$ & $\begin{array}{l}\text { Five Year Development } \\
\text { Plan sets out specific } \\
\text { targets for general and } \\
\text { higher education and for } \\
\text { technical and vocational } \\
\text { training with the } \\
\text { establishment of Human } \\
\text { Resource Development } \\
\text { Fund. } \\
\text { Financial support is } \\
\text { given to firms } \\
\text { committed to training } \\
\text { nationals. }\end{array}$ & $\begin{array}{l}\text { School curricula } \\
\text { have been } \\
\text { revised to focus } \\
\text { on vocational } \\
\text { training. } \\
\text { Local } \\
\text { government and } \\
\text { chambers of } \\
\text { commerce } \\
\text { provide training } \\
\text { and internships } \\
\text { financed by their } \\
\text { own resources. }\end{array}$ \\
\hline $\begin{array}{l}\text { Enhance private } \\
\text { sector benefits }\end{array}$ & & $\begin{array}{c}\text { Extend payment of } \\
\text { the social allowance } \\
\text { for Kuwaiti workers } \\
\text { in the private sector. } \\
\text { Payment of } \\
\text { unemployment } \\
\text { benefits for workers } \\
\text { until they find a job. }\end{array}$ & $\begin{array}{l}\text { Initiate the extension of } \\
\text { the pension scheme to the } \\
\text { private sector to increase } \\
\text { its attractiveness. }\end{array}$ & & $\begin{array}{l}\text { A benefit } \\
\text { pension scheme } \\
\text { for nationals in } \\
\text { the private sector } \\
\text { was introduced } \\
\text { in } 1999 . \\
\text { Foreigners are } \\
\text { subject to higher } \\
\text { water and } \\
\text { electricity tariff } \\
\text { rates. }\end{array}$ \\
\hline $\begin{array}{l}\text { Civil service } \\
\text { retrenchment }\end{array}$ & & & $\begin{array}{l}\text { Reduction in the number } \\
\text { of civil servants by } 13,500 \\
\text { from 1996- } 98 \text {. }\end{array}$ & & \\
\hline $\begin{array}{l}\text { Mobility, } \\
\text { placement }\end{array}$ & $\begin{array}{c}\text { Employment } \\
\text { Service Bureau } \\
\text { created in } 1997\end{array}$ & & $\begin{array}{l}\text { Additional flexibility in } \\
\text { the dismissal legislation. } \\
\text { Expatriate workers are }\end{array}$ & $\begin{array}{l}\text { The labor ministry's job } \\
\text { matching and placement } \\
\text { program is currently run }\end{array}$ & $\begin{array}{l}\text { In 1997, transfer } \\
\text { of sponsorships } \\
\text { between }\end{array}$ \\
\hline
\end{tabular}




\begin{tabular}{|c|c|c|c|c|c|}
\hline $\begin{array}{l}\text { support, and } \\
\text { information } \\
\text { dissemination } \\
\text { policies }\end{array}$ & $\begin{array}{l}\text { to handle job } \\
\text { matching and } \\
\text { placement } \\
\text { support for } \\
\text { Bahraini job } \\
\text { seekers. }\end{array}$ & & $\begin{array}{l}\text { allowed with the approval } \\
\text { of their employer to move } \\
\text { between sponsors, without } \\
\text { being forced to leave the } \\
\text { country. }\end{array}$ & $\begin{array}{l}\text { in } 37 \text { regional labor } \\
\text { offices, with } 5 \text { more } \\
\text { expected to open in } \\
2000-01 \text { with special } \\
\text { focus on private sector } \\
\text { vacancies. }\end{array}$ & $\begin{array}{c}\text { employers } \\
\text { became possible } \\
\text { after one year of } \\
\text { service subject } \\
\text { to the approval } \\
\text { of all parties. }\end{array}$ \\
\hline $\begin{array}{l}\text { Enforcement of } \\
\text { legislation on } \\
\text { visa } \\
\text { requirements } \\
\text { and work } \\
\text { restrictions }\end{array}$ & $\begin{array}{c}\text { Recent } \\
\text { campaign to } \\
\text { enforce } \\
\text { immigration law. } \\
\text { Illegal workers } \\
\text { are offered a } \\
\text { grace period to } \\
\text { legalize their } \\
\text { stay or leave the } \\
\text { country. Failure } \\
\text { to comply would } \\
\text { result in legal } \\
\text { action. }\end{array}$ & $\begin{array}{l}\text { Recent campaign to } \\
\text { enforce immigration } \\
\text { law. Illegal workers } \\
\text { are offered a grace } \\
\text { period to legalize } \\
\text { their stay or leave } \\
\text { the country. Failure } \\
\text { to comply would } \\
\text { result in legal action. }\end{array}$ & & $\begin{array}{l}\text { Recent campaign to } \\
\text { enforce immigration } \\
\text { law. Illegal workers are } \\
\text { offered a grace period to } \\
\text { legalize their stay or } \\
\text { leave the country. } \\
\text { Failure to comply would } \\
\text { result in legal action. }\end{array}$ & $\begin{array}{c}\text { Recent } \\
\text { campaign to } \\
\text { enforce } \\
\text { immigration law, } \\
\text { including that } \\
\text { expatriates } \\
\text { should work } \\
\text { only for their } \\
\text { sponsor. Illegal } \\
\text { workers are } \\
\text { offered a grace } \\
\text { period to } \\
\text { legalize their } \\
\text { stay or leave the } \\
\text { country. Illegal } \\
\text { workers can be } \\
\text { subject to } \\
\text { imprisonment } \\
\text { for up to } 3 \text { years } \\
\text { and fined up to } \\
\text { Dh } 30,000 \text {. }\end{array}$ \\
\hline $\begin{array}{l}\text { Unemployment } \\
\text { benefits }\end{array}$ & & $\begin{array}{l}\text { The Manpower and } \\
\text { Government } \\
\text { Restructuring } \\
\text { Program established } \\
\text { in } 2001 \text { will provide } \\
\text { benefits to Kuwaiti } \\
\text { nationals. }\end{array}$ & & & \\
\hline
\end{tabular}

Source: Updated from Table 3 in Megarbane (2001).

\section{APPENDIX II}

\section{A MATCHING MODEL OF EMPLOYMENT FOR NATIONALS IN THE GCC ECONOMIES}

\section{Basic Setup}

There are two types of agents - national workers and private-sector firms. Nationals either are employed by firms or search for employment. Firms with vacancies search for employees to fill their vacancies. A filled or a matched position produces output. Matches are broken exogenously.

\section{Workers}

Suppose that there are $N_{t}$ nationals in the labor force at time $t$, and suppose that the national labor force is growing at a rate, $g_{N}$. Workers are identical, infinitely lived, risk neutral, and are indexed on the interval $\left[0, N_{t}\right]$. They have a common discount factor, $\beta=1 /(1+r)$, where $r$ is the world real interest rate. 
When employed by a private-sector firm, a worker receives a wage, $w$. Assume further that an employed worker also receives benefits, $b_{E} \geq 0$, from the government. Therefore, the total compensation of an employed national in the private sector is $w+b_{E}$.

When not employed, a worker is assumed to have a reservation wage, $b_{u}$, that reflects the benefits and payments received from the government. The higher the benefits and payments, the higher the reservation wage.

\section{Firms}

Firms employ workers to produce output based on a constant-returns-to-scale technology. Assume that one worker, when employed, produces $y$ units of output. The level of output per worker, or equivalent labor productivity, depends upon the level of technology (or total factor productivity) and capital per worker. Improvements in technology and higher levels of capital per worker raise labor productivity and output. Increases in the level of skill (or efficiency of the worker), $h$, also raise output.

When a job is filled, the firm pays the employee, $w$, and earns, $(y-w)$. When a job is vacant, the firm incurs a cost, $c$, of searching for an employee. If there is a small number of suitable nationals, then it may be quite costly for firms to search for them.

Jobs, or matches, are destroyed with probability $s$; that is, at each point in time, a fraction $s$ of employed workers loses their jobs. In other words, $s$ is the given separation rate. When a match is destroyed, firms must pay a separation cost, $c_{s}$. For higher values of $c_{s}$, job destruction is more costly for the firm.

Assume that firms are owned by nationals, which is an appropriate assumption for the GCC countries. Consequently, firms have the same discount factor as nationals, $\beta=1 /(1+r)$.

\section{Matching Function}

Successful matches between nationals looking for private-sector employment and firms looking to hire workers is given by the matching function, $M(U, V)$, where $M$ denotes the number of successful matches, $U$ is the number of unemployed nationals, and $V$ is the number of job vacancies posted by firms. Assume that $M(U, V)$ is homogeneous of degree one. Let $q$ denote the probability of filling a vacancy, $M(U, V) / V$. Let $\theta$ be a measure of the tightness of the labor market, $V / U$; as the labor market becomes tighter, $\theta$ increases. Note that since $M(U, V)$ is homogeneous of degree one, $q$ is a function of $\theta: q(\theta)=M(U, V) / V$. Furthermore, the probability of an unemployed national finding a job is $\theta q(\theta)=M(U, V) / U$.

Assume for simplicity, as in the literature, that $M=A U^{\alpha} V^{l-\alpha}$, where $\alpha \in(0,1)$ is the elasticity of matches with respect to unemployment, and $A$ is the efficiency of the matching "technology" or process. Measures that raise $A$ increase the efficiency of the process and shorten the time to find a match. These measures comprise information dissemination and, more generally, job search support, including internships. 


\section{Solution of the Model}

In each time period, there is a flow of young nationals, including women, entering the work force and looking for jobs. Unemployed workers are also looking for jobs. Existing jobs, or matches, are being destroyed with probability $s$. At the same time, firms are looking to fill vacancies, and $M$ successful matches are occurring. Therefore, the change in unemployment is given by:

$$
U_{t+1}=U_{t}+\left(N_{t+1}-N_{t}\right)+s\left(N_{t}-U_{t}\right)-\theta_{t} q\left(\theta_{t}\right) U_{t}
$$

Dividing by $N_{t}$, substituting for the unemployment rate, $u=U / N$, and rewriting the equation yields:

$$
\left(1+g_{N}\right) u_{t+1}=\left(s+g_{N}\right)+\left[1-s-\theta_{t} q\left(\theta_{t}\right)\right] u_{t}
$$

with $\left[s+g_{N}\right]$ referring to the increase in the unemployment rate due to the flow into unemployment, and $\theta q(\theta) u$ referring to the decrease due to the flow out of unemployment through successful matches.

In steady state, $u$ is constant. The steady state unemployment rate, $u^{s s}$, is

$$
u^{s s}=\frac{s+g_{N}}{s+g_{N}+\theta^{s s} q\left(\theta^{s s}\right)}
$$

where $\theta^{s s}$ is the steady state value for the market tightness indicator, $\theta$. The impact of an increase in labor force growth, $g_{N}$, implies a rise in steady state employment for a constant level of $\theta^{s} q\left(\theta^{s}\right)$.

To close the model, we need to solve for $\theta^{\text {ss }}$. We do this under two scenarios. The first scenario describes the current state in GCC labor markets where, in general, wages may be thought of as given by the internationally competitive wage, $w^{*}$. Workers have no bargaining power as firms have access to an elastic supply of expatriate workers at $w^{*}$. The second scenario describes a possible situation where there are quantitative restrictions on the employment of expatriates, giving some bargaining power to national workers.

\section{Case 1: No wage bargaining}

To solve for $\theta^{\text {ss }}$, consider the firm's valuation of a filled job and a vacancy. The valuation of a filled job, $V_{J}$, is given as follows:

$$
V_{J}=\left(y-w^{*}\right)+\beta\left[s\left(-c_{s}+V_{V}\right)+(1-s) V_{J}\right]
$$

In the current period, the firm earns profits of $y-w^{*}$. In the next period, the match is broken with probability $s$; the firm pays the separation cost, $c_{s}$, and will have the valuation of a vacancy, $V_{V}$. With probability $(1-S)$, the match will continue and the firm will have the valuation of a filled position, $V_{J}$.

The valuation of a vacancy, $V_{V}$, is given by: 


$$
V_{V}=-c+\beta\left[q\left(\theta^{s s}\right) V_{J}+\left\{1-q\left(\theta^{s s}\right)\right\} V_{V}\right]
$$

The firm incurs a cost, $c$, of searching. In the next period, the vacancy is filled with probability, $q\left(\theta^{s s}\right)$, and the firm will receive a valuation, $V_{J}$. With probability, $1-q\left(\theta^{s}\right)$, the vacancy is not filled, and the firm will receive, $V_{V}$.

The zero profit condition, following from free entry, implies $V_{V}=0$, which leaves two equations in two unknowns, $V_{J}$ and $\theta^{s s}$. The solution for $\theta^{s s}$ and $u^{s s}$ are given by:

$$
u^{s s}=\frac{\theta^{s s}=\left[\frac{A}{c} \frac{\left(y-w^{*}-\beta s c_{s}\right)}{(r+s)}\right]^{1 / \alpha}}{1+\left(s+g_{N}\right)^{-1} A^{\frac{1}{\alpha}} c^{1-\frac{1}{\alpha}}\left(y-w^{*}-\beta s c_{s}\right)^{\frac{1}{\alpha}-1}(r+s)^{1-\frac{1}{\alpha}}}
$$

The comparative statistics are given by:

$$
u^{s s}=u\left(y, A, \quad s, \quad c, \quad c_{s}, w^{*}, g_{N}\right)
$$

In other words, the unemployment rate increases with increases in the separation rate, $s$, the cost of searching, $c$, the wage rate, $w^{*}$, and the cost of separation (or firing), $c_{s}$. It reduces with increases in productivity, $y$, and the efficiency of the matching process, $A$. Therefore, lowering the unemployment rate entails enacting measures to increase the productivity of the non-oil private sector, $y$, including through human capital investment, and institutional reforms that raise the efficiency of the matching process, $A$, and reduce the costs of searching, $c$, and of separation, $c_{s}$. In addition, investment in human capital can lower the probability of separation, $s$, and, hence, the unemployment rate.

\section{Case 2: Expatriate labor restrictions and wage bargaining}

Restrictions on the employment of skilled and semi-skilled expatriates lead to an increase in the bargaining power of national workers vis-à-vis firms. Therefore, wages are no longer determined by the internationally competitive wage, but by a bargaining process between national employees and firms.

To solve for $\theta^{s s}$, consider the worker's valuation of being employed versus being unemployed. When employed, the worker's valuation is given by:

$$
V_{E}=\left(w+b_{E}\right)+\beta\left[s V_{U}+(1-s) V_{E}\right],
$$

where $V_{U}$ is the valuation when unemployed. In the current period, the worker receives wages and benefits of $w+b_{E}$. In the subsequent period, the worker becomes unemployed with probability $s$ and receives a valuation $V_{U}$, or remains employed with probability $(1-s)$. 
When unemployed, the worker's valuation is:

$$
V_{U}=b_{U}+\beta\left[\theta^{s s} q\left(\theta^{s s}\right) V_{E}+\left\{1-\theta^{s s} q\left(\theta^{s s}\right)\right\} V_{U}\right]
$$

In the current period, the unemployed worker receives payments of $b_{U}$ from the government. With probability $\theta^{s} q\left(\theta^{s s}\right)$, the worker finds employment, but remains unemployed with probability $1-\theta^{s} q\left(\theta^{s}\right)$.

Note that if $w+b_{E}<b_{U}$, then workers find it more beneficial to remain "unemployed"- at the expense of the government. Reducing unemployment, therefore, entails reducing "unemployment" benefits or public sector compensation, if the public sector is continuing to act as the employer of last resort.

The bargaining process is characterized by Nash bargaining. The total match surplus, $S$, is the sum of the worker's and the employer's share: $S \equiv\left(V_{E}-V_{U}\right)+V_{J}$, where $V_{J}=(y-w)+\beta\left[s\left(-\mathrm{c}+V_{v}\right)+(1-s) V_{J}\right]$ is the firm's valuation of a filled position [21]. It is shared according to the Nash product:

$$
\begin{aligned}
& \max _{\left(V_{E}-V_{U}\right), V_{J}}\left(V_{E}-V_{U}\right)^{\phi} V_{J}^{1-\phi} \\
& \text { s.t. } \quad S=\left(V_{E}-V_{U}\right)+V_{J}
\end{aligned}
$$

where $\phi \in[0,1]$ is the worker's share of the one-period surplus. Indeed, $\left(V_{E}-V_{U}\right)=\phi S$ and $V_{J}=(1-\phi) S$. If $\phi=0$, the firm captures the entire surplus, whereas if $\phi=1$, the worker captures the entire surplus.

The solution for $w$ and $\theta^{s}$ may be derived from the following four equations:

$$
\begin{gathered}
V_{E}-V_{U}=\frac{w+b_{E}-b_{U}}{1-\beta\left[1-s-\theta^{s s} q\left(\theta^{s s}\right)\right]}=\frac{w+b_{E}-b_{U}}{1-\beta\left[1-s-A\left(\theta^{s s}\right)^{1-\alpha}\right]} \\
V_{J}=\frac{c}{\beta q\left(\theta^{s s}\right)}=\frac{c}{\beta A\left(\theta^{s s}\right)^{-\alpha}} \\
V_{J}=\frac{y-w-\beta s c_{s}}{1-\beta(1-s)} \\
\frac{V_{E}-V_{U}}{V_{J}}=\frac{\phi}{1-\phi}
\end{gathered}
$$

The equations may be re-written to show that:

$$
w=\phi\left(y-\beta s c_{s}+c \theta^{s s}+b_{E}-b_{U}\right)-\left(b_{E}-b_{U}\right)
$$

Since $\phi=0$ corresponds to the case of $w=w^{*}, \phi>0$ implies $w>w^{*}$. 
Further algebra may be used to show that the steady state unemployment rate, $u^{s s}$, is obtained by solving the following two equations:

$$
\begin{gathered}
u^{s s}=\frac{1}{1+\left(s+g_{N}\right)^{-1} \theta^{s s} q\left(\theta^{s s}\right)}=\frac{1}{1+\left(s+g_{N}\right)^{-1} A\left(\theta^{s s}\right)^{1-\alpha}} \\
c[1-\beta(1-s)]\left(\theta^{s s}\right)^{\alpha}+c \beta A \phi \theta^{s s}=\beta A(1-\phi)\left(y-\beta s c_{s}+b_{E}-b_{U}\right)
\end{gathered}
$$

The comparative statistics are as follows:

$$
\begin{aligned}
& u^{s s}=u\left(y, \quad A, \quad s, \quad c, \quad c_{s}, \phi, \quad b_{E}, \quad b_{U}, g_{N}\right) \\
& -\quad++++-+
\end{aligned}
$$

The difference between this specification and the earlier one is the endogenous determination of wages. The signs in all other variables remain as before. An increase in the bargaining power of nationals, reflected in an increase in $\phi$, raises the wages of nationals at the expense of firm profitability. This results in an increase in the unemployment rate. An increase in unemployment compensation also raises the unemployment rate by raising the wage at which nationals are employed in the private sector. On the other hand, greater government benefits to nationals employed in the private sector lowers the unemployment rate because workers are willing to accept lower wages from firms, which increases the firm's surplus.

\section{Endnotes}

* The authors wish to thank Edward Gardner, Zubair Iqbal, and Philippe Callier for providing comments and useful suggestions on this paper. We also thank Patrick Megarbane for letting us reproduce parts of his paper.

[1] The GCC countries include Bahrain, Kuwait, Oman, Qatar, Saudi Arabia, and the United Arab Emirates.

[2] Labor statistics in GCC countries - Bahrain, Kuwait, Oman, Qatar, Saudi Arabia, and the United Arab Emirates (U.A.E.) — are scant and vary significantly across countries in terms of coverage, quality, measurement, and timeliness. In addition, the data available are incomplete because information on military and security personnel is excluded. Statistics on unemployment are also not regularly collected.

[3] The United Nations Arab Human Development Report (2002) projects for the GCC area a sharp increase in the population aged 0 to 14, from close to 9 million in 2000 to 14 million by 2010 .

[4] See the United Nations Development Program (2002), Chapter 3.

[5] In the U.A.E., Goyal (2003) estimated that labor growth accounted for nearly one-third of non-oil growth in the 1980s, and more than one-half in the following decade. 
[6] This phenomenon, know as the Dutch disease, refers to the negative output and employment effects caused by an oil (or natural resource) boom on the non-oil sector of the economy, particularly exports, leading to an overall contraction in the country's tradable sector.

[7] In the 1970s and 1980s, most expatriate workers were coming from other Arab countries.

[8] In most GCC countries, the retirement age for men is 60 years old and for women 55 years old, but they can retire with full benefits after 20 years of service. In addition, in all of these countries, employee contribution to the pension fund is relatively low (5 percent) or nil (Qatar). Expatriate workers are not covered by retirement benefits, but they usually receive a month's salary for every year of service as compensation.

[9] The reservation wage is the threshold wage at or above which national workers would decide to supply their labor services and below which they would not.

[10] Illiteracy is mainly concentrated among women and the population aged 40 years and above. For instance, in Saudi Arabia, illiteracy among the female population was almost 29 percent in 2000, while it was less than 3 percent for the population below 29 years.

[11] According to Al-Lamki (2002), in Oman, the remuneration package in the government sector for unskilled and semi-skilled work is twice that of the private sector.

[12] In Oman, the target for nationalization of the labor force was only achieved in the banking sector (set at 90 percent), reflecting the opportunity provided to nationals through education (a banking institute was created in the early 1980s) to acquire the skills required by the sector.

[13] Goyal (2003) analyzed national employment in the U.A.E. using a simple labor demand and supply model.

[14] The standard literature has primarily examined unemployment dynamics in the context of business cycles and the secular rise of unemployment in Europe.

[15] Detailed derivations are provided in Appendix II.

[16] The model follows the setup in Ljungqvist and Sargent (2000).

[17] Note that $y$ also denotes average labor productivity.

[18] This would constitute a one-time increase in levels of employment.

[19] The fiscal cost will need to be less than the employment benefit for the policy to be welfare improving. These subsidies could be financed, for instance, by fees on skilled expatriate workers. 
[20] Such investment would increase output and productivity, $y$, and matching efficiency, A, and reduce the separation probability, $\mathrm{s}$, and the cost of search, $c$.

[21] Recall that the firm's valuation of a vacancy is $V=0$, owing to the zero profit assumption.

\section{References}

Al Lamki, Salma M, 2002, "A Three Tier Strategic Framework for Human Resource Management and Training in the Sultanate of Oman," Journal of Comparative International Management, Vol. 24, (No. 1) (May), pp.75-86.

Central Statistical Organization, State of Qatar, 1998, Annual Statistical Abstract.

Gardner, Edward, 2003, “Wanted: More Jobs," Finance and Development, Vol. 40, (No. 1), pp. 18-21.

Goyal, Rishi, 2003, "Non-Oil Growth, Competitiveness, and the Labor Market," in United Arab Emirates-Selected Issues and Statistical Appendix (Washington: International Monetary Fund), pp. 41-58.

Ljungqvist, Lars, and Thomas J. Sargent, 2000, Recursive Macroeconomic Theory (Cambridge, Mass.: MIT Press).

Megarbane, Patrick, 2001, "Labor Market Issues in the GCC Countries," in The Cooperation Council of the Arab States of the Gulf $(G C C)$ : Strategy for Sustainable Growth with Macroeconomic Stability (unpublished; Washington: International Monetary Fund).

Ministry of Planning, State of Kuwait, 2001, Annual Statistical Abstract.

Ministry of Planning, Kingdom of Saudi Arabia, Seventh Development Plan, 2000-04.

Ministry of Labor and Social Affairs, State of Bahrain, 1997, Bahrain: Maximizing Human Resources.

United Nations Development Program, 1998, Human Development Report State of Bahrain: Achievements and Challenges of Human Development. University of Bahrain Press (Manama, Bahrain).

— 